\title{
ॠUSGS
}

science for a changing world

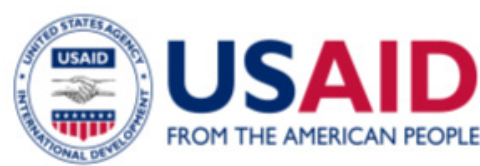

\section{Assessment of Existing and Potential Landslide Hazards Resulting from the April 25, 2015 Gorkha, Nepal Earthquake Sequence}

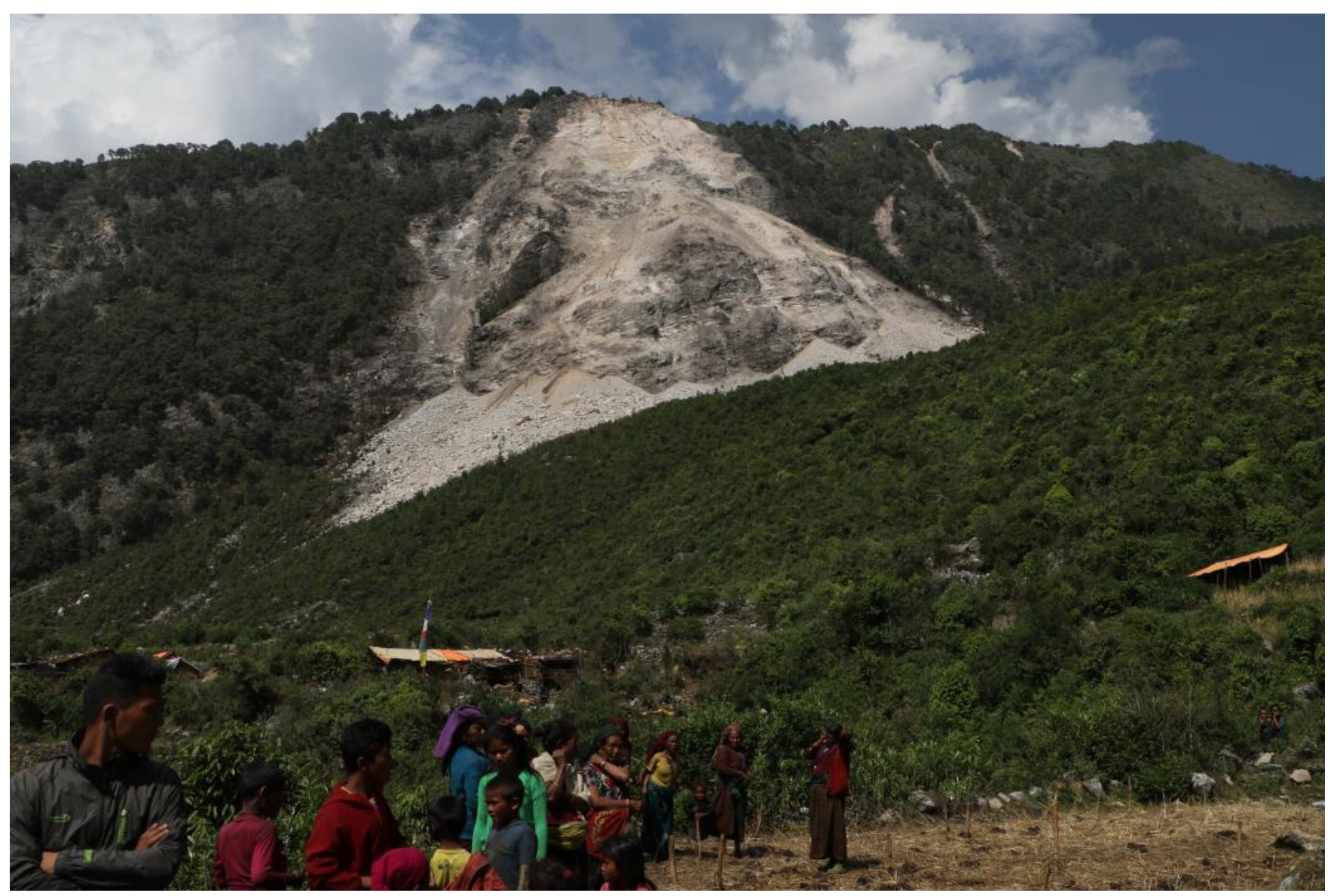

Open-File Report 2015-1142 Version 1.1, August 2015 
Cover: Villagers in Kerauja below a 500-m-long, 210-m-wide rock slide that resulted in one fatality. 


\section{Assessment of Existing and Potential Landslide Hazards Resulting from the April 25, 2015 Gorkha, Nepal Earthquake Sequence}

By Brian D. Collins and Randall W. Jibson

Open-File Report 2015-1142

Version 1.1, August 2015 


\title{
U.S. Department of the Interior SALLY JEWELL, Secretary
}

\section{U.S. Geological Survey \\ Suzette M. Kimball, Acting Director}

\author{
U.S. Geological Survey, Reston, Virginia \\ First release: 2015 \\ Revised: August 2015 (ver. 1.1)
}

For more information on the USGS—-the Federal source for science about the Earth, its natural and living resources, natural hazards, and the environment-visit http://www.usgs.gov/ or call 1-888-ASK-USGS (1-888-275-8747).

For an overview of USGS information products, including maps, imagery, and publications, visit http://www.usgs.gov/pubprod/.

Any use of trade, firm, or product names is for descriptive purposes only and does not imply endorsement by the U.S. Government.

Although this information product, for the most part, is in the public domain, it also may contain copyrighted materials as noted in the text. Permission to reproduce copyrighted items must be secured from the copyright owner.

Suggested citation:

Collins, B.D., and Jibson, R.W., 2015, Assessment of existing and potential landslide hazards resulting from the April 25, 2015 Gorkha, Nepal earthquake sequence (ver. 1.1, August 2015): U.S. Geological Survey Open-File Report 2015-1142, 50 p., http://dx.doi.org/10.3133/ofr20151142.

ISSN 2331-1258 (online) 


\section{Acknowledgments}

Funding for this work was provided by the U.S. Department of State, USAID_Office of Foreign Disaster Assistance and the U.S. Geological Survey (USGS), Landslide and Earthquake Hazards Programs. We acknowledge the following groups for their assistance and cooperation with identifying areas of investigation before field work commenced: U.S. National Science Foundation sponsored Geoengineering Extreme Event Reconnaissance Team (GEER), British Geological Survey, University of Durham (England), International Centre for Integrated Mountain Development (ICIMOD), National Aeronautics and Space Administration (NASA), and the NASA-ICIMOD volunteer mapping team. In particular, we thank the following individuals who provided critical observations of landslides based on their assessment of satellite imagery: Ed Harp and Robert Schmitt (USGS), Nick Rosser and Alex Densmore (University of Durham), Jeff Kargel (University of Arizona), Dan Shugar (University of Washington), Marin Clark (University of Michigan), and Dalia Kirschbaum (NASA). Binod Tiwari (California State University, Fullerton), Youssef Hashash (University of Illinois), Sagar Bajracharya (ICIMOD), and Christopher Madugo (Pacific Gas and Electric Company) assisted with helicopter reconnaissance. Skye Corbett (USGS) provided GIS and graphics support, and he, along with Jeff Coe, Ryan Gold, and Mark Reid (all USGS) provided reviews on a tight schedule. This work was made possible by the last-minute administrative efforts of John Galetzka (UNAVCO), Jeffrey Caravelli, Kimberly Jenkins, Kathleen Keillor, Jennifer Kershner, Gari Mayberry, Kara Spritzer, and especially Don Shannon of the USGS. Finally, Captain Pasang Norbu Sherpa of Mountain Helicopters, Nepal provided outstanding professionalism and generous hospitality during our stay in Nepal. His expertise in flying through Nepal's extreme topography, along with his local knowledge of earthquake-affected areas, were vital to the success of this project. 


\section{Contents}

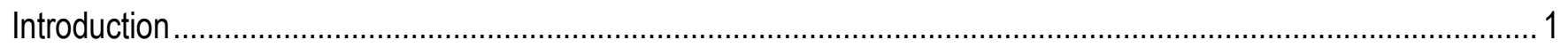

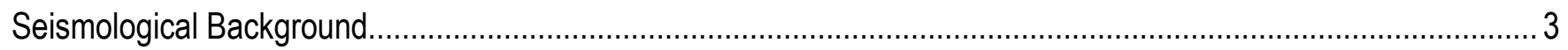

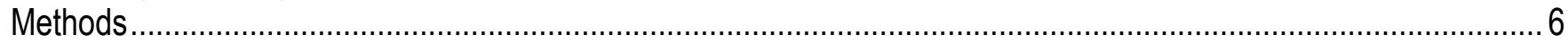

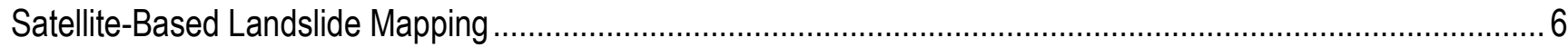

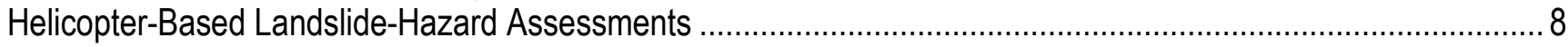

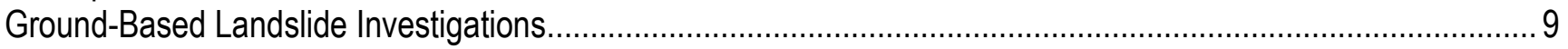

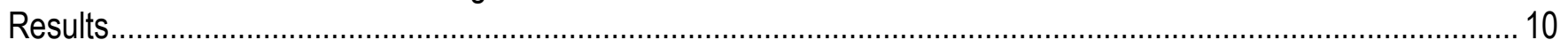

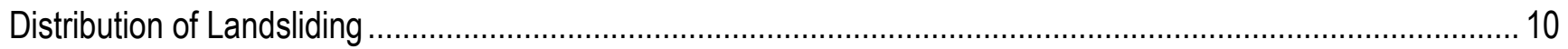

Assessment of Valley-Blocking Landslides ........................................................................................ 12

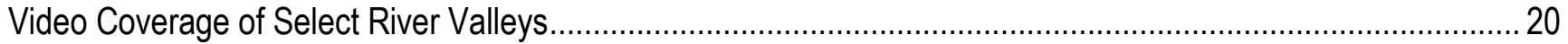

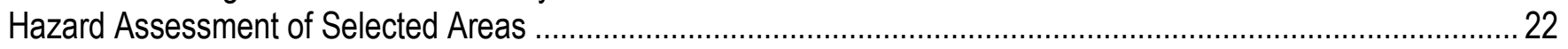

Baisari Landslide Dam (Kali Gandaki River, Myagdi District) ........................................................................ 25

Marsyangdi Valley Landslide Dams (Marsyangdi River, Manang District) ......................................................2 29

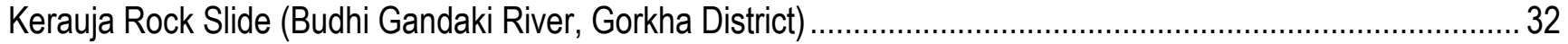

Langtang Debris Avalanche (Langtang River, Rasuwa District) ................................................................. 34

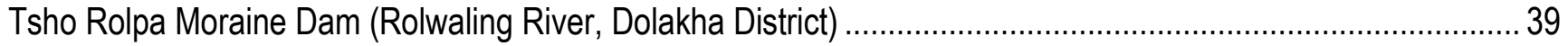

Potential Landslide Hazards Associated with the 2015 Summer Monsoon ........................................................ 43

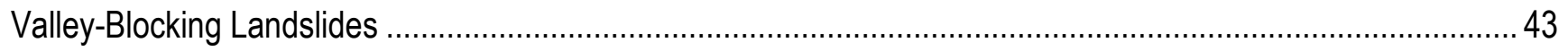

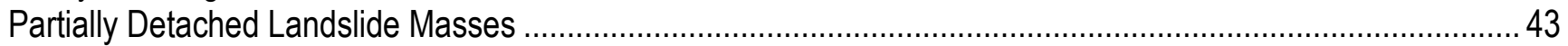

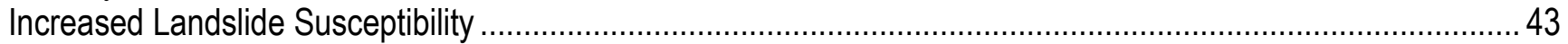

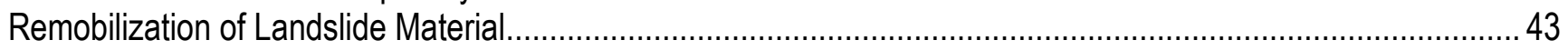

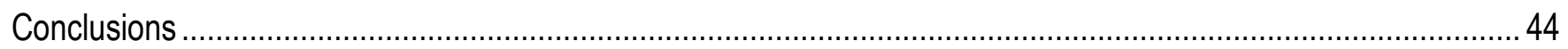

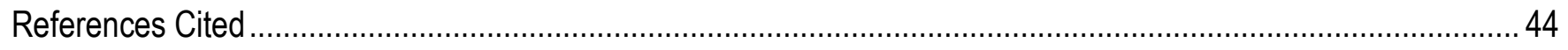

Appendix 1. Video and Geographic Reference Files from Helicopter Reconnaissance.......................................... 47

\section{Figures}

1. Images showing landslides triggered by the April and May 2015 Gorkha earthquake sequence in central Nepal.

2. Regional map of Nepal showing major 2015 Gorkha sequence earthquake epicenters with dates, and 20 Nepal district boundaries where landslides were investigated

3. USGS ShakeMaps showing estimated seismic intensity in the central Nepal region from the M7.8 April 25, 2015 Gorkha, Nepal earthquake, and the M7.3 May 12, 2015 aftershock.

4. Regional map of central Nepal showing priority investigation areas developed from satellite-imagery-based investigation, media reports, and in-country agency (ICIMOD) suggestions..

5. Photograph showing high-performance, high-altitude helicopter required to reach remote, and in some cases, high-altitude areas where earthquake shaking triggered thousands of landslides............................ 8

6. Regional map of Nepal showing GPS track logs of helicopter-based reconnaissance flight paths superimposed on priority investigation areas............................................................................... 9

7. Photograph showing Captain Pasang Norbu Sherpa translating information from villagers in Kerauja (Gorkha district) to USGS researcher Randall Jibson. 
8. Regional map of central Nepal showing approximate limits of landslides resulting from the April 25, 2015 Gorkha, Nepal earthquake and subsequent aftershocks (including M7.3 earthquake on May 12, 2015) .... 12

9. Regional map of central Nepal showing locations of valley-blocking landslides identified during helicopterand satellite-based reconnaissance.

10. Histogram plots of valley-blocking landslide volume and valley-blocking landslide lake impoundment at the time of our assessment (May 27 to June 1, 2015), approximately one month following the main earthquake

11. Regional map of Nepal showing helicopter flight path lines and areas where video coverage was collected.

12. Photographs showing rock slide along the Kali Gandaki River on May 24, 2015 that buried the village of Baisari and blocked the flow of the river for 16 hours nearly one month following the main earthquake shock

13. Photograph showing existing lake impoundment formed by May 24,2015 rock slide at Baisari village ...... 27

14. Photograph showing rock fall from landslide scarp (as expressed by dust cloud) five days after the failure, indicates continuing hazard in the Baisari area.

15. Aerial image of the Pisang 2 earth slide along the Marsyangdi River upstream from Pisang village. As of May 30, 2015, this landslide constricted the river with a 350-m-long slackwater lake upstream of the landslide deposit

16. Aerial images of the Humde 1 and Humde 2 earth slides along the Marsyangdi River downstream from Humde village.

17. Photographs showing fatal rock slide above Kerauja village in Gorkha district.

18. Photographs showing the Langtang debris avalanche, which destroyed the entire village of Langtang either through direct deposition or by consequent air blast

19. Photograph showing source area of Langtang debris avalanche was in ice slopes above 5,000 m elevation

20. Photograph showing blown down trees caused by rapid emplacement of the Langtang debris avalanche deposit and resulting radial air blast

21. Photograph showing the Langtang debris avalanche deposit temporarily blocking the flow of the Langtang River, which subsequently formed a tunnel through the ice in which the river was flowing through in May 2015

22. Photograph showing eastward view of the terminal moraine forming Tsho Rolpa glacial lake ....................40

23. Photograph showing the sluice gates used to control the lake elevation at Tsho Rolpa ............................. 41

24. Photographs showing lateral spreading at the inlet to the Tsho Rolpa engineered drainage channel ......... 42

\section{Tables}

1. Locations and characteristics of select valley-blocking landslides 14

2. Locations and characteristics of landslides where site-specific assessments were performed. 23

A1. Helicopter video file log. 48 


\section{Datum and Map Information}

Horizontal coordinate information is referenced to the World Geodetic System of 1984 (WGS84) in degrees of latitude and longitude.

All elevations are approximate heights in meters above Mean Sea Level (MSL), as referenced to the WGS84 ellipsoid corrected to orthometric height using the Earth Gravitational Model of 1996 (EGM96) geoid.

Base image for all maps was developed from Esri's ArcGIS online webmap service (http://www.arcgis.com/home/ webmap/viewer.html?useExisting=1).

International boundaries portrayed on all maps reflect U.S. government policy (https://hiu.state.gov/data) and thus not necessarily de facto control. Areas under dispute are identified as dashed border lines on all maps. 


\title{
Assessment of Existing and Potential Landslide Hazards Resulting from the April 25, 2015 Gorkha, Nepal Earthquake Sequence
}

\author{
By Brian D. Collins and Randall W. Jibson
}

\section{Introduction}

On April 25, 2015, a large (M7.8) earthquake shook much of central Nepal and was followed by a series of $M>6$ aftershocks, including a $M 7.3$ event on May 12, 2015. This earthquake and aftershocks, referred to as the "Gorkha earthquake sequence," caused thousands of fatalities, damaged and destroyed entire villages, and displaced millions of residents. The earthquakes also triggered thousands of landslides in the exceedingly steep topography of Nepal; these landslides were responsible for hundreds of fatalities, and blocked vital roads and trails to affected villages (fig. 1). Landslides caused by the Gorkha earthquake sequence continue to pose both immediate and long-term hazards to villages and infrastructure within the affected region. Some landslides blocked rivers and thus created another potential concern for villages located downstream.

With the support of the United States Agency for International Development (USAID), Office of Foreign Disaster Assistance (OFDA), and in collaboration with earthquake-hazard organizations from both the United States (for example, U.S. National Science Foundation Geoengineering Extreme Event Reconnaissance [GEER] Team) and Nepal (International Centre for Integrated Mountain Development [ICIMOD]), the U.S. Geological Survey (USGS) responded to this crisis by providing landslide-hazard expertise to Nepalese agencies and affected villages. In addition to collaborating with an international group of remote-sensing scientists to document the spatial distribution of landsliding in the first few weeks following the earthquake, the USGS conducted in-country landslide hazard assessments for 10 days beginning May 24, 2015. Much of the information obtained by the USGS during their time in Nepal was conveyed directly to affected villages and government agencies as opportunities arose. Upon return to the United States, data organization, interpretation, and synthesis began immediately to provide a rapid assessment of landslide hazards for use by Nepalese agencies during the 2015 summer monsoon (typically occurring from June through September).

This report provides a detailed account of assessments performed in May and June 2015 and focuses on valley-blocking landslides because they have the potential to pose considerable hazard to many villages in Nepal. First, we provide a seismological background of Nepal and then detail the methods used for both external and in-country data collection and interpretation. Our results consist of an overview of landsliding extent, a characterization of all valley-blocking landslides identified during our work, and a description of video resources that provide high resolution coverage of approximately 1,000 kilometers $(\mathrm{km})$ of river valleys and surrounding terrain affected by the Gorkha earthquake sequence. This is followed by a description of site-specific landslide-hazard assessments conducted while in Nepal and includes detailed descriptions of five noteworthy case studies. Finally, we assess the expectation for additional landslide hazards during the 2015 summer monsoon season. 

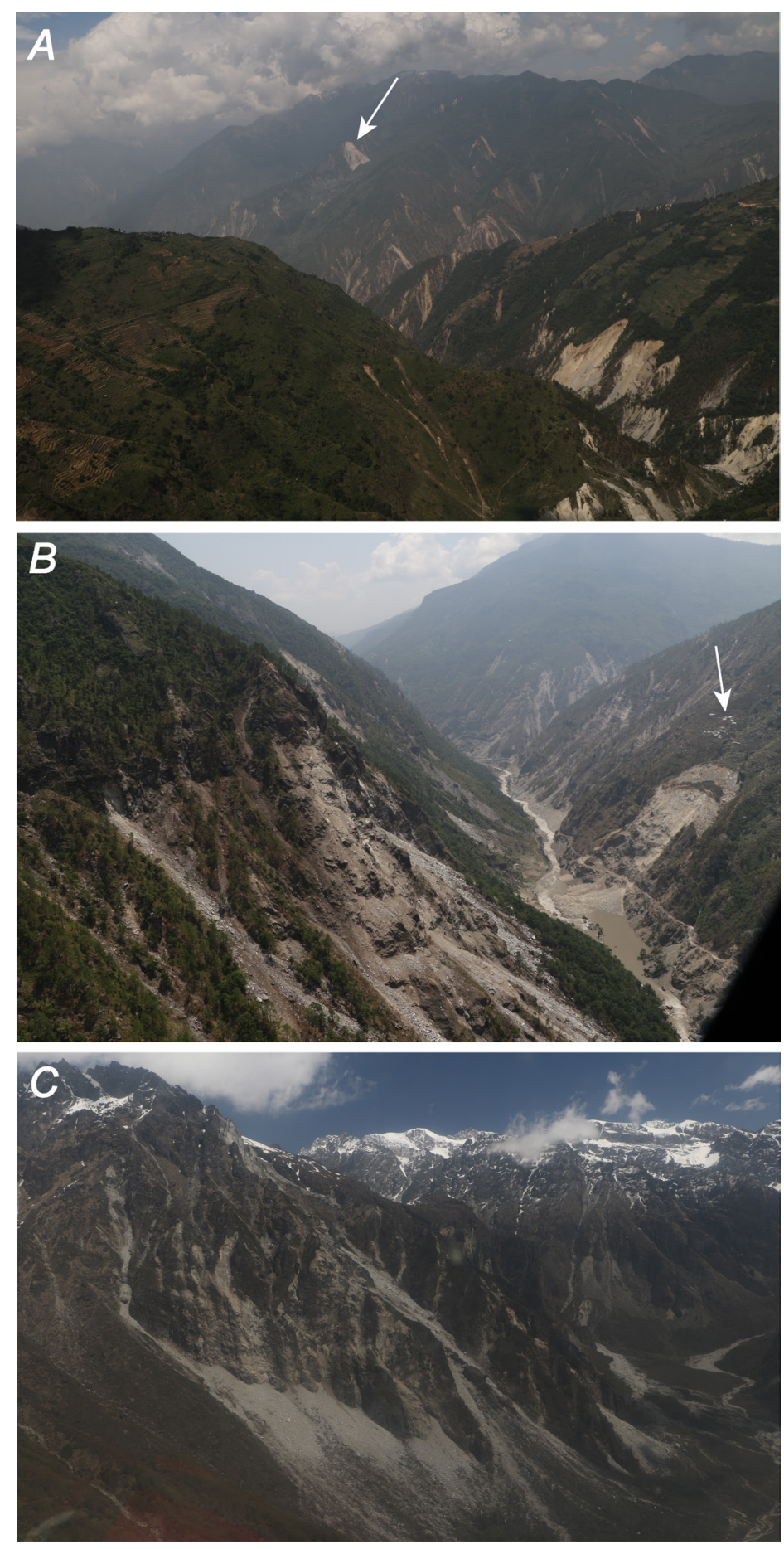

Figure 1. Images showing landslides triggered by the April and May 2015 Gorkha earthquake sequence in central Nepal. A, Widespread ridgetop landsliding in Gorkha district. The Kerauja rock slide (see cover image of this report) is wide scar on ridge visible in photograph background (arrow). B, Partially breached Gogane landslide dam in Rasuwa district. Top of scarp below village (arrow) is approximately $400 \mathrm{~m}$ above river level. $C$, Rock falls in the Urkin Kangari Valley, Sindhupalchok district. Image shows approximately 1,200 $\mathrm{m}$ relief between top of foreground cliffs and valley floor. 


\section{Seismological Background}

Nepal lies along the boundary of the Indian and Eurasian continental tectonic plates; northward underthrusting of India beneath Eurasia at a rate of 40-50 millimeters per year ( $\mathrm{mm} / \mathrm{yr})$ (http://earthquake.usgs.gov/earthquakes/eventpage/us20002926\#general_summary) generates numerous earthquakes and makes this an area of high seismicity. This plate-boundary region has a history of large and great earthquakes - prior to 2015, three events of $M \geq 6$ occurred in this region over the past two centuries. In August 1988, a M6.8 earthquake occurred about $160 \mathrm{~km}$ southeast of Kathmandu near the border of Nepal and India. This earthquake caused an estimated 1,000 fatalities in Nepal and India (http://earthquake.usgs.gov/earthquakes/world/events/1988_08_20.php). The largest earthquake (M8.1) to affect the region in the past 200 years occurred in 1934 and is known as the "Nepal-Bihar earthquake" (Auden and Ghosh, 1934; Singh and Gupta, 1980; Ambraseys and Douglas, 2004); it ruptured a large fault section east of the 2015 event. The Nepal-Bihar earthquake severely damaged Kathmandu and caused about 10,700 fatalities (http://earthquake.usgs.gov/earthquakes/world/events/ 1934_01_15.php). Finally, in 1833, an earthquake estimated at M7.7 (Bilham, 1995, 2004) occurred north or northeast of Kathmandu and is thought to have ruptured an area similar to the 2015 Gorkha earthquake sequence (http://earthquake.usgs.gov/earthquakes/eventpage/ us20002926\#general_summary).

The April 25, 2015 Gorkha, Nepal earthquake (M7.8) occurred as a result of thrust faulting along the main interface between the subducting Indian plate and the overriding Eurasian plate to the north. The epicenter was located at N28.147 ${ }^{\circ}$ E84.708 (http://earthquake.usgs.gov/earthquakes/eventpage/ us20002926\#scientific_origin) near the village of Barpak, about $77 \mathrm{~km}$ northwest of Kathmandu (fig. 2). Fault rupture propagated southeastward with maximum slip of 4-6 meters $(\mathrm{m})$ beneath the Kathmandu Valley. The focal-plane mechanism indicates pure thrust on a plane striking $295^{\circ}$, dipping $11^{\circ}$ north, and having a focal depth of $10 \mathrm{~km}$ (http://earthquake.usgs.gov/earthquakes/eventpage/ us20002926\#scientific_summary). Preliminary reports indicate that no surface rupture occurred from this earthquake or any of the subsequent aftershocks. The only strong-motion record available at this time (July 2015) was located in Kathmandu and had a peak ground acceleration (PGA) of only $0.16 \mathrm{~g}$ $\left(1 \mathrm{~g}=9.81 \mathrm{~meters} / \mathrm{second}\right.$ squared $\left.\left[\mathrm{m} / \mathrm{s}^{2}\right]\right)(\mathrm{http} / / /$ www.strongmotioncenter.org/cgi-bin/CESMD/ iqr_dist_DM2.pl?iqrID=Lamjung_us20002926\&SFlag=0\&Flag=2). The USGS ShakeMap (http://earthquake.usgs.gov/earthquakes/eventpage/us20002926\#impact_shakemap) model for the earthquake (fig. $3 A$ ) indicates that localized areas likely experienced PGA values exceeding $1 \mathrm{~g}$; this is consistent with our field observations, discussed subsequently.

The Gorkha, Nepal earthquake was followed by hundreds of aftershocks. In the two months following the main shock, there was 1 aftershock with $M>7,2$ aftershocks in the $M 6-7$ range, 22 in the M5-6 range, and 39 in the $M 4-5$ range (http://www.seismonepal.gov.np/ index.php?action=earthquakes\&show=recent). The largest aftershock (M7.3) occurred on May 12, 2015 about $75 \mathrm{~km}$ east-northeast of Kathmandu in Dolakha district (fig. 2) with an epicenter at N27.819 E86.080 (http://earthquake.usgs.gov/earthquakes/eventpage/us20002ejl\#scientific_origin). The focalmechanism solution of this aftershock indicates pure thrust on a plane striking $312^{\circ}$ and dipping $11^{\circ}$ north, with a focal depth of $15 \mathrm{~km}$ (http://earthquake.usgs.gov/earthquakes/eventpage/ us20002ej1\#scientific_summary). Maximum fault slip of about $3 \mathrm{~m}$ occurred south of the epicenter. The USGS ShakeMap model (http://earthquake.usgs.gov/earthquakes/eventpage/ us20002ejl\#impact_shakemap) of the earthquake (fig. 3B) indicates maximum PGA values of about $0.83 \mathrm{~g}$, which are again consistent with our observations in this area and discussed subsequently in more detail. 


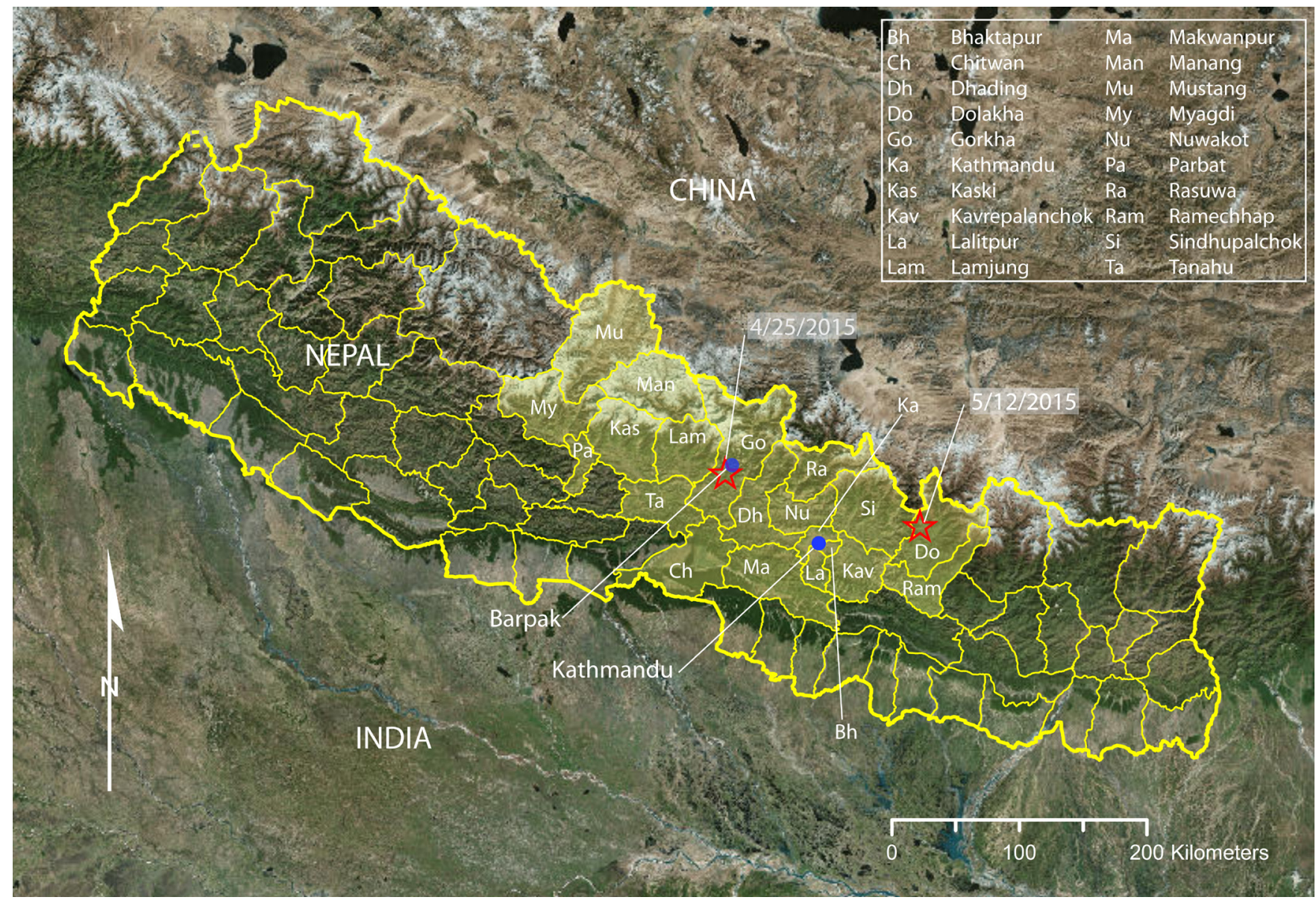

Figure 2. Regional map of Nepal showing major 2015 Gorkha sequence earthquake epicenters with dates (stars), and 20 Nepal district boundaries (yellow shading) where landslides were investigated. 


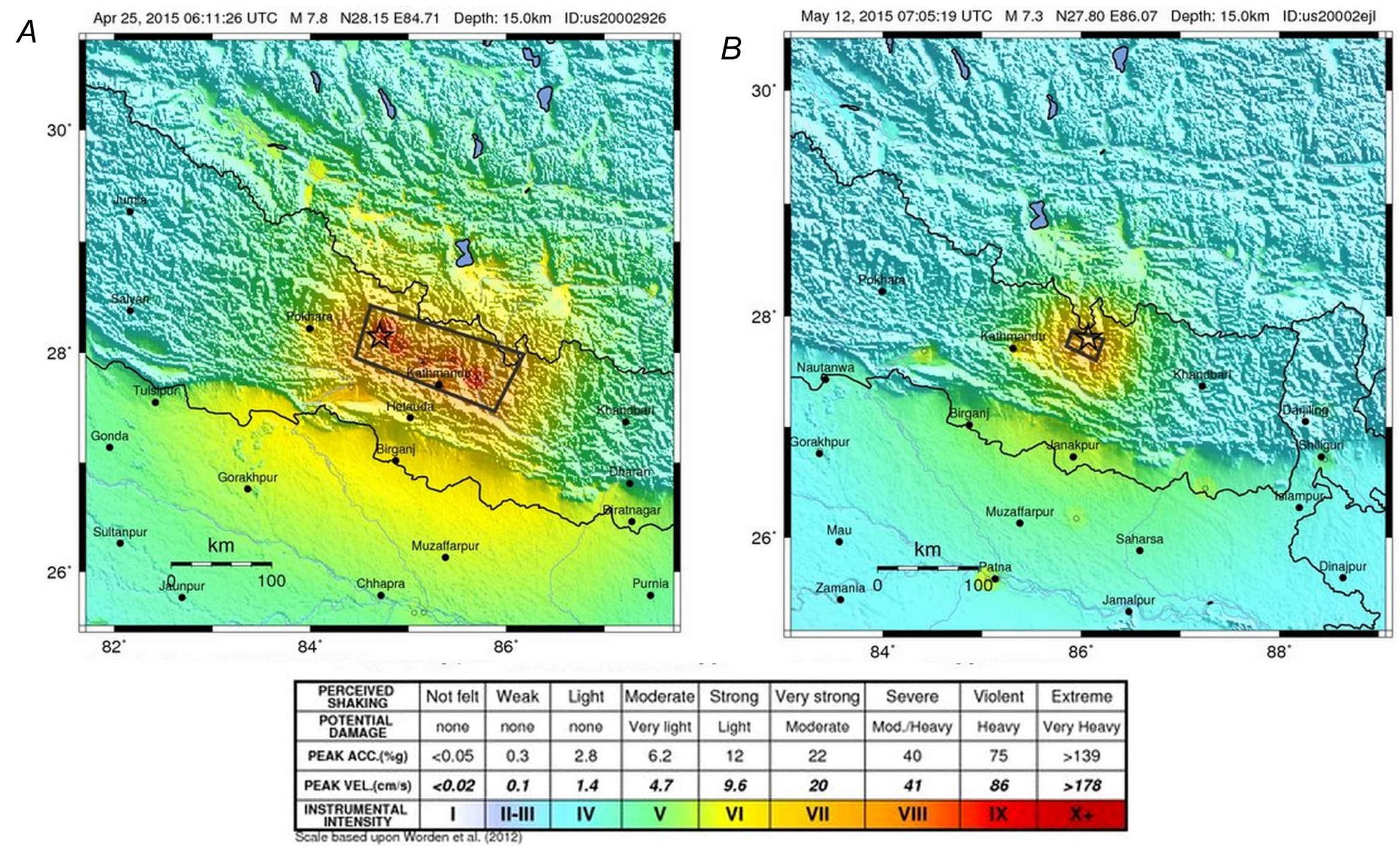

Figure 3. USGS ShakeMaps showing estimated seismic intensity in the central Nepal region from the M7.8 April 25, 2015 Gorkha, Nepal earthquake $(A)$, and the M7.3 May 12, 2015 aftershock $(B)$. 


\section{Methods}

\section{Satellite-Based Landslide Mapping}

Immediately following the April 25, 2015 Gorkha, Nepal earthquake, the international landslide community began examining post-earthquake satellite imagery to identify areas affected by landslides. This group of organizations and individuals (see "Acknowledgments" section of this report) selforganized to discretize Nepal into sections for subsequent landslide-inventory mapping. Rapidly disseminated maps were available on the internet from several organizations (for example, NASA, British Geological Survey, Engineers without Frontiers, ICIMOD), and these products (for example, http://earthobservatory.nasa.gov/IOTD/view.php?id=85977) [last accessed July 14, 2015];

(http://ewf.nerc.ac.uk/2015/06/30/updated-30-june-landslide-inventory-following-25-april-and-12-maynepal-earthquakes/) [last accessed July 14, 2015]; (http://www.icimod.org/?q=17904) [last accessed July 14, 2015], along with individual observations by many persons involved in the landslide mapping, provided us with a list of priority areas for in-country investigation. These included several observations of landslides that entirely blocked valleys and therefore posed significant hazard with respect to landslide dam burst and consequent catastrophic flooding downstream. Following meetings with ICIMOD on May 26, 2015, we finalized the list of priority areas to include 12 general areas where landslide hazards were likely to be very high (fig. 4). In some cases, additional targets for investigation within these priority areas were added as new satellite imagery became available during the time of our field-assessment effort. 


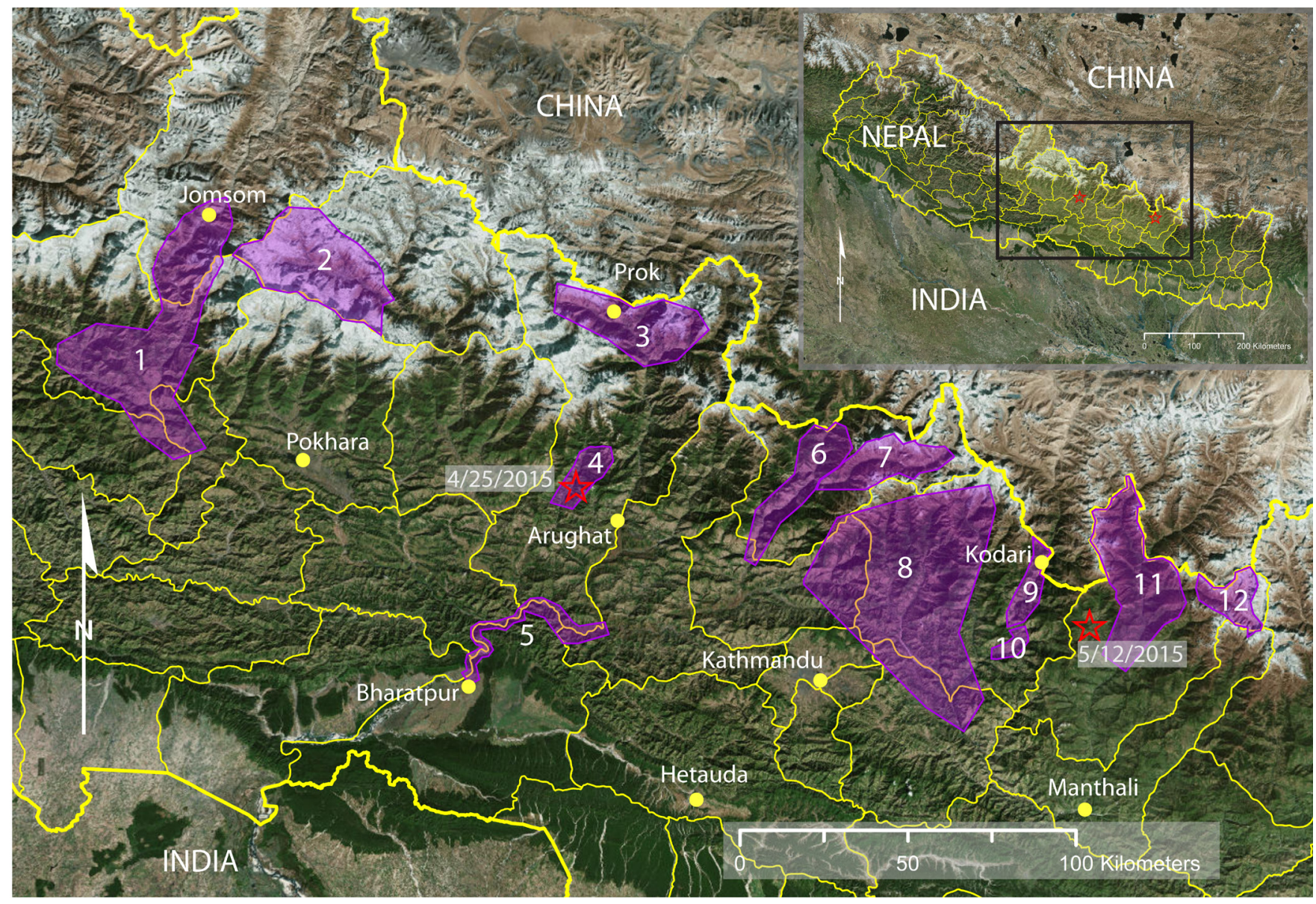

Figure 4. Regional map of central Nepal showing priority investigation areas (purple-shaded regions) developed from satellite-imagery-based investigation, media reports, and in-country agency (ICIMOD) suggestions. Priority investigation areas are as follows: (1) Kali Gandaki valley, (2) Marsyangdi valley, (3) Budhi Gandaki valley, (4) Barpak, (5) Prithvi Highway, (6) Upper Trishuli valley, (7) Langtang valley, (8) Melamchi valley, (9) Upper Bhote Koshi valley, (10) Sun Koshi, (11) Upper Tama Koshi, and (12) Tsho Rolpa. Nepal district boundaries are delineated by yellow lines. Major earthquake epicenters with dates are represented by red stars. Select city place names (yellow dots) are included for geographic reference. 


\section{Helicopter-Based Landslide-Hazard Assessments}

We performed helicopter-based assessment of landslide hazards in each of the 12 priority areas, totaling five days of flying time, beginning May 27, 2015. An Airbus AS350 B3e helicopter was required to reach remote, and in some cases, high-altitude $(>5,000 \mathrm{~m})$ areas during some of the flight missions (fig. 5). All helicopter missions began and ended at Kathmandu's Tribhuvan International Airport and were generally of four-hour duration to provide for refueling halfway through the day. Flight paths generally followed river valleys; we first flew upstream for an overview and to identify safe landing zones, and then returned downstream for additional ground stops at identified assessment target areas. In total, we traveled approximately 3,200 km of flight distance over five days (fig. 6).

Two landslide researchers, one positioned at either side of the helicopter, documented existing landslide hazards during flight; in some cases, a third researcher also made observations from the backmiddle seat. Two pilots operated the helicopter and also provided local information and knowledge of particularly hard-hit landslide areas. We also mounted a small video camera (GoPro Hero4 Silver) to the front of the helicopter to collect high-resolution video imagery of select sections of our flight paths. In total, we collected approximately 6,000 still-photo images of landslide-affected regions and video coverage of approximately 1,000 km of flight path. This documentation, along with additional attributes gleaned from ground-based reconnaissance, form the core information used to complete the landslidehazard assessments.

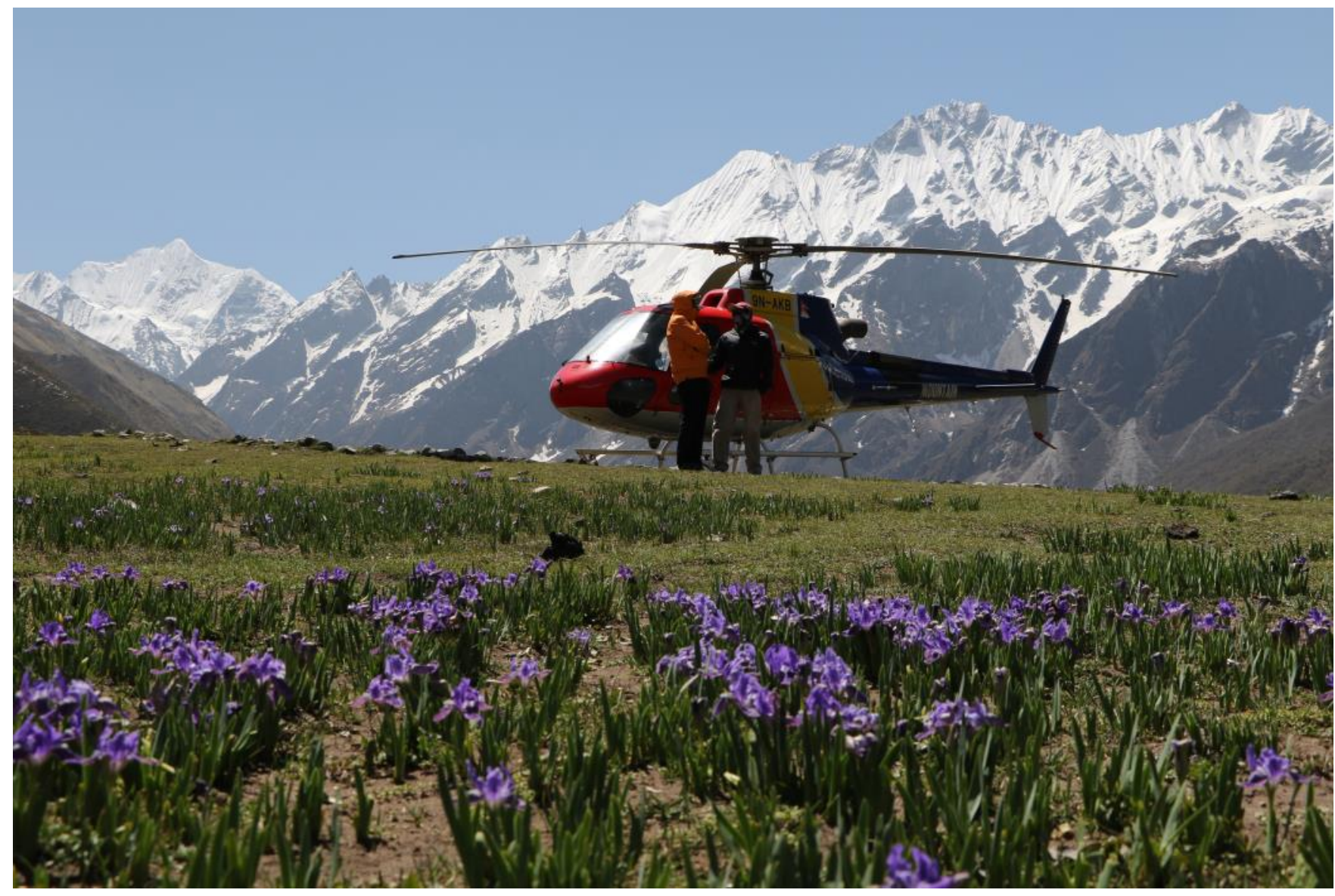

Figure 5. Photograph showing high-performance, high-altitude helicopter required to reach remote, and in some cases, high-altitude areas where earthquake shaking triggered thousands of landslides. 


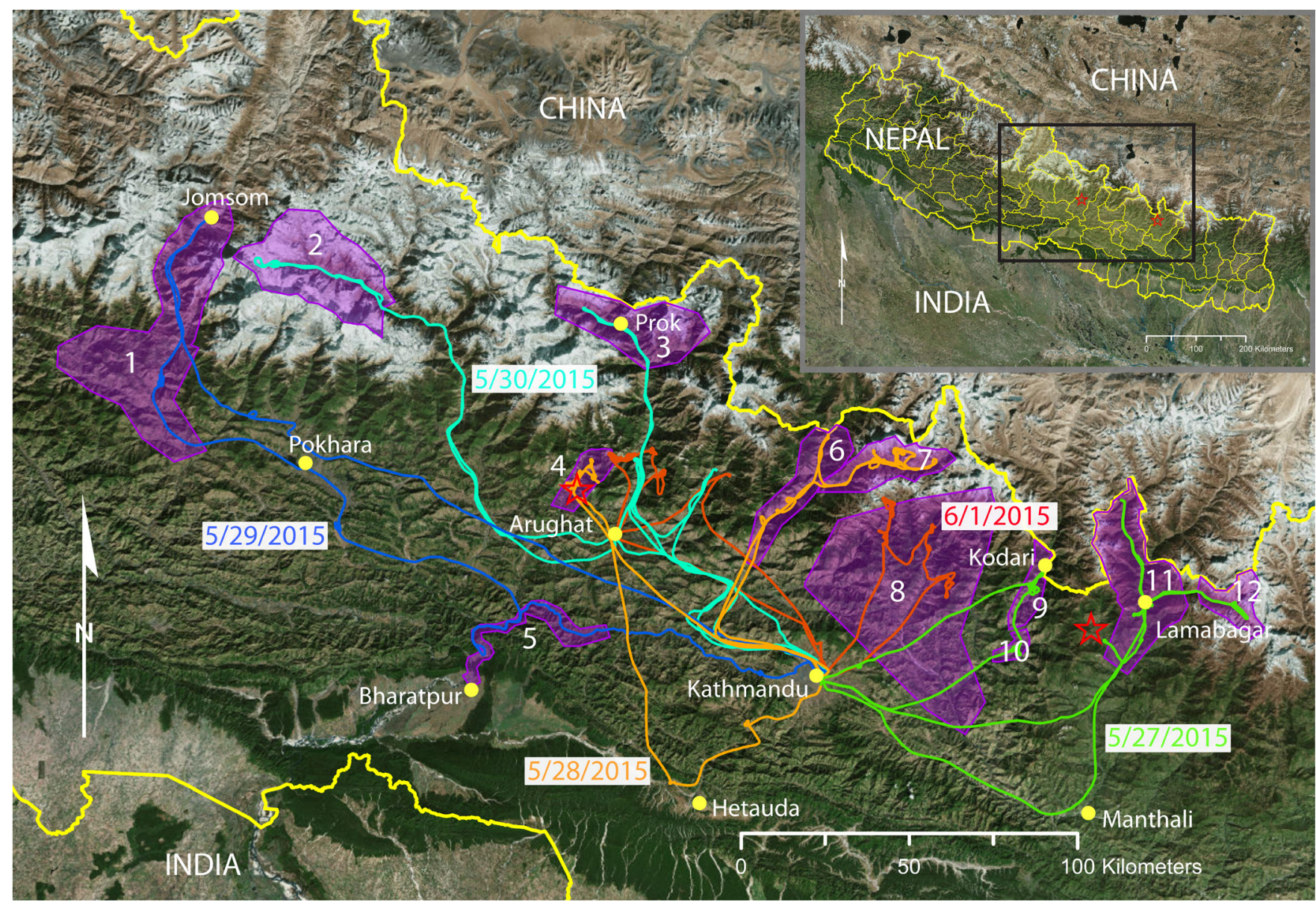

Figure 6. Regional map of Nepal showing GPS track logs of helicopter-based reconnaissance flight paths superimposed on priority investigation areas (purple shading; see fig. 4 caption for priority investigation area names corresponding to numbers). Color of each flight path line corresponds to date (in M/DD/YYYY format) of same color. Major earthquake epicenters are represented by red stars. Select city place names (yellow dots) are included for geographic reference.

\section{Ground-Based Landslide Investigations}

We completed ground-based investigations at priority target areas (such as landslide dams previously identified using satellite imagery) and at other landslides that were deemed significant ongoing hazards. These investigations were generally focused on evaluating immediate and short-term ( $\sim 6$ month) expected hazards resulting from (1) ongoing progressive gravitational failure of landslide masses, (2) additional seismic shaking from aftershocks, (3) future expected precipitation, and (or) (4) increasing upstream flow during the upcoming 2015 summer monsoon season (for landslide dams). At each location, we made on-site assessments of landslide type (for example, rock slide, rock fall, debris flow, debris avalanche, according to Varnes, 1978; Highland, 2004), estimated dimensions and volumes, classified rock type (where accessible), measured fractures (where visible and accessible), and interviewed eye witnesses and villagers (fig. 7) who had local knowledge of both the recent failure and history of the slope area that failed (for example, whether the slope was a place of recent, preearthquake landsliding). In some cases, additional close-up aerial inspections of main-scarp areas were conducted to assess the likelihood of potential catastrophic failure versus smaller and more minor rock 
fall or surficial sliding. Ground investigations normally lasted 30-60 minutes; results were recorded photographically and in field notebooks and were conveyed to local officials and villagers, when present.

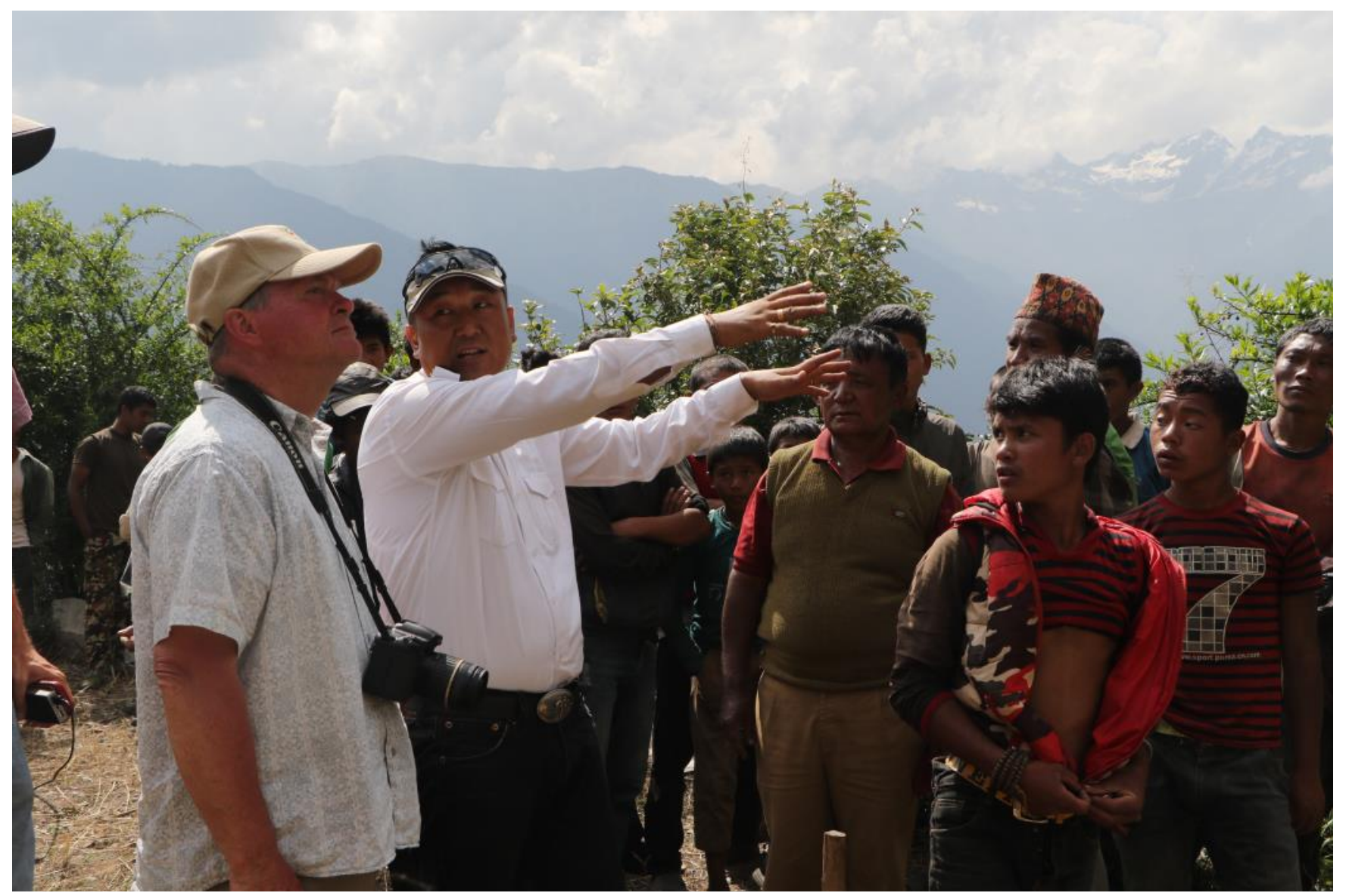

Figure 7. Photograph showing Captain Pasang Norbu Sherpa translating information from villagers in Kerauja (Gorkha district) to USGS researcher Randall Jibson. Ground-based reconnaissance was commonly performed by interviewing local villagers and government authorities familiar with both the current and previous history of landsliding.

\section{Results}

\section{Distribution of Landsliding}

Our investigation extended into most major drainages in the broad epicentral region of the Gorkha earthquake sequence (fig. 6). We saw thousands of landslides during our reconnaissance and we estimate that the total number of landslides triggered is in the few tens of thousands, which includes landslides in China that were not directly investigated in the field. This estimate is consistent with relations (derived from other earthquakes) between earthquake magnitude and number of landslidesthe relation of Malamud and others (2004) predicts about 25,000 landslides, and Keefer's (2002) relation predicts about 60,000 landslides for a $M 7.8$ earthquake. Virtually all of the landslides were falls and slides of rock and soil (see, for example, fig. 1), which is consistent with observations from other worldwide earthquakes (Keefer, 1984, 2002). Failure surfaces generally were parallel to the slope and 
1-10 m deep. In most cases, sliding occurred in fractured, weathered, surficial material. The humid climate and steep topography of the area have created a deep (several meters) zone of weathered and fractured material susceptible to failure. The highly destructive Langtang debris avalanche (described subsequently) is perhaps an exception to this landslide characterization because it involved a large volume of ice, but it likewise failed on a slope-parallel surface.

Limits of significant landsliding were observed in some of our traverses (fig. 8). To the west of the main shock epicenter, landslides were sparse or absent along most reaches of the Kali Gandaki valley (fig. 4), and we place a limit in that direction roughly along that valley. We flew south as far as Hetauda, at the boundary between the Himalayan foothills and flatter terrain (Terai region) to the south. Landslides in steep valleys north of Hetauda decreased in size and number as we flew south. The boundary of landslide-susceptible terrain was observed at about the point where it appeared that shaking had attenuated to a level at which few landslides were triggered, and so we place a southern landslide limit along the mountain front where the Himalayan foothills begin. To the east of the main shock epicenter, the landslide limit is complicated by the occurrence of the $M 7.3$ aftershock; in most cases, it is difficult or impossible to determine which earthquake triggered landslides in a specific area. During our reconnaissance, we observed evidence of a few recent rock falls in the Tsho Rolpa area of Dolakha district, but widespread landsliding was absent. However, we propose an eastern limit approximately 90 $\mathrm{km}$ to the east of Tsho Rolpa, in the vicinity of Mount Everest base camp, based on eye-witness accounts of rock falls and a fatal avalanche from the main earthquake shock. The actual landslide limit probably lies somewhere east of that location, but we have no specific evidence other than the reports from Everest base camp. The landslide limit to the north is undetermined because it lies in China, in which we did not perform reconnaissance. Based on these observed limits, we estimate the total area affected by landsliding in Nepal to be about 30,000 square kilometers $\left(\mathrm{km}^{2}\right)$. The total landslide area is larger (perhaps by as much as 25 percent) because it extended into China; recent satellite-imagery mapping suggests that landsliding extended about $30 \mathrm{~km}$ into China from the border with Nepal (see, for example, http://ewf.nerc.ac.uk/2015/06/30/updated-30-june-landslide-inventory-following-25-april-and12-may-nepal-earthquakes/) [last accessed July 14, 2015].

In general, landslide concentrations were highest near the epicenter of the main Gorkha, Nepal earthquake, but significant landslide concentrations extended about twice as far to the east than to the west. This likely was the result of the eastward-directed fault rupture of the main shock as well as the occurrence of the M7.3 aftershock east of the main shock. 


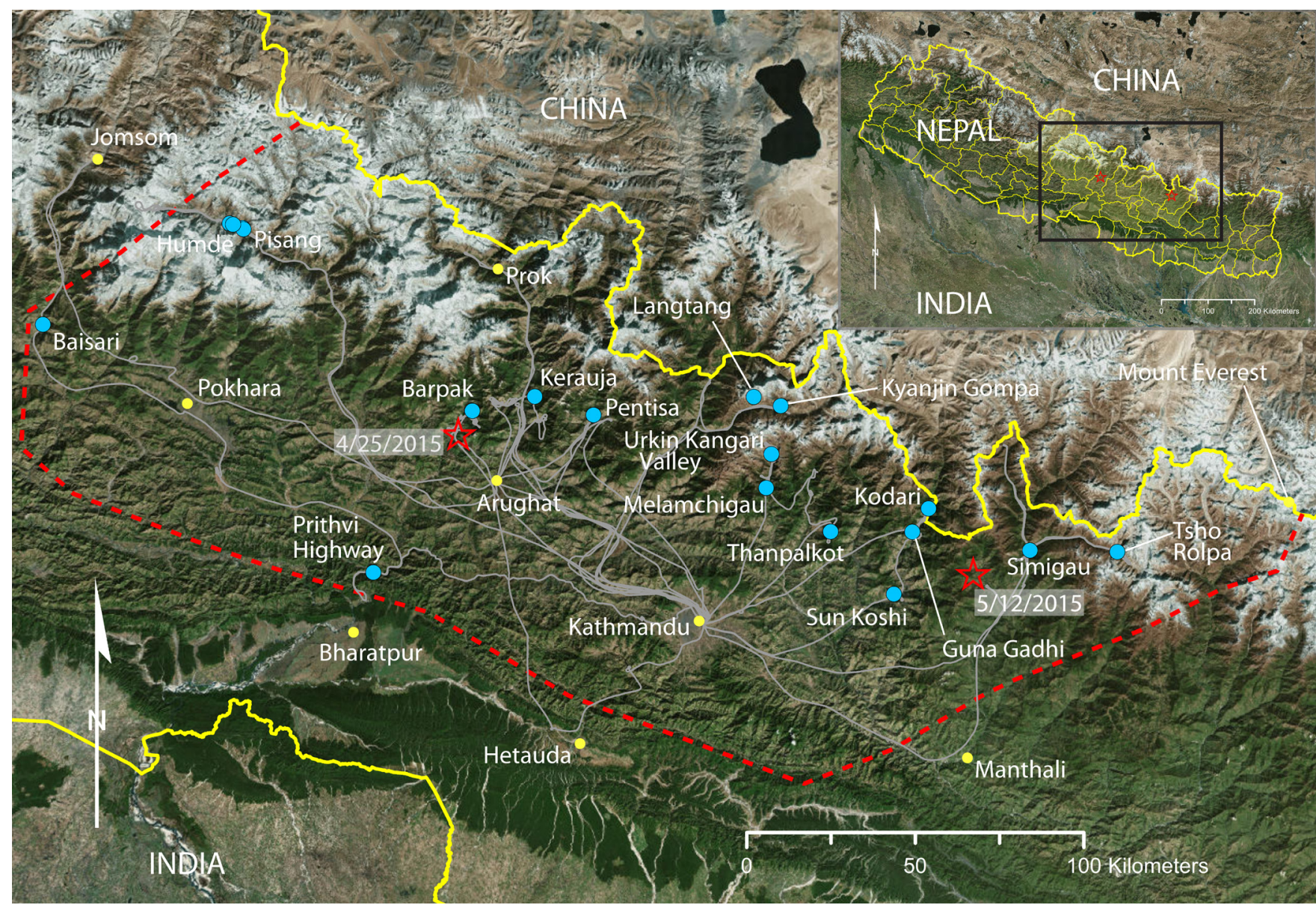

Figure 8. Regional map of central Nepal showing approximate limits of landslides (red dashed line) resulting from the April 25, 2015 Gorkha, Nepal earthquake and subsequent aftershocks (including M7.3 earthquake on May 12 2015). Locations of select areas where landslide hazard assessments were performed are indicated by blue dots. Major earthquake epicenters with dates are represented by red stars. Select city place names (smaller yellow dots) are included for geographic reference. Yellow lines show political boundaries.

\section{Assessment of Valley-Blocking Landslides}

We assessed 69 landslide dams in the earthquake-affected region (table 1; fig. 9). This inventory is not complete and only reflects those features identified during our helicopter-based assessments and subsequent analysis of our data sets. We limited our evaluations to landslides that dammed named rivers or significantly large tributaries listed on official topographic maps published by the Government of Nepal's Survey Department. Dams ranged in volume from 500 to 2,000,000 cubic meters $\left(\mathrm{m}^{3}\right)$, averaged approximately $50,000 \mathrm{~m}^{3}$ and had a median volume of $6,500 \mathrm{~m}^{3}$ (fig. 10A). The average is skewed towards the high end due to a single large landslide - the Langtang debris avalanche (described in a subsequent section). Only half of the dams had lakes impounded either because rivers were dry at the time of the earthquakes or, more commonly, because the dams had already been breached. For those with impounded lakes, the lake surface areas ranged between 50 and 35,000 square meters $\left(\mathrm{m}^{2}\right)$ and averaged $1,700 \mathrm{~m}^{2}$. Only 18 dams had lakes exceeding $500 \mathrm{~m}^{2}$ in surface area. The lack of dams having large impoundments (that is, those $>500 \mathrm{~m}^{2}$ in surface area) at the time of our assessment (May 27-June $1,2015)$ is a welcome observation given the statistics for landslide dams. Using a database of 73 natural 
landslide dams in which the time to failure after formation is known, Costa and Schuster (1988) show that only 56 percent fail within one month. In our judgment, the small volume of most landslides causing river blockage was the primary reason for the lack of longevity of the dams; many landslides only formed dams that were two or three times the height of the existing river depth. Thus, filling of the impoundment and subsequent overtopping of the dams likely occurred within a few days of dam formation. This hypothesis is corroborated by interviews with local villagers in several locations. Near Humde, a landslide dam is reported to have breached five days after formation, the large landslide dam at Baisari (among the largest occurring from the earthquakes) breached within one day, and a small landslide dam near Pentisa overtopped after seven days.

The primary mode of drainage for lakes impounded by most landslide dams appeared to be from overtopping; this was corroborated by reports from local villagers we interviewed at the time of our assessments. In most cases, impoundments were narrow $(<100 \mathrm{~m})$ and do not appear to have exceeded 1 $\mathrm{km}$ in length. One exception to this is the Baisari rock slide landslide dam, which backed up the Kali Gandaki River for approximately $3 \mathrm{~km}$ following formation. This landslide dam did breach catastrophically as observed by vastly increased river flows downstream. Fortunately, no fatalities occurred because local emergency-management officials evacuated downstream areas before the landslide dam breached. Breaching in some other cases was also likely rapid given the fine-grained and highly erodible deposits in which they were formed (for example, all landslide dams formed on the Marsyangdi River). Where valleys were steeper, and where mountain rivers were already narrow and boulder-choked, new landslide dams formed and did not completely breach by overtopping. Instead, piping of finer material through conduits formed by large boulders allowed the landslide-dammed lakes to drain. Some dams were comprised only of rock and allowed low river flows to pass with only partial restriction. In some other cases, rivers were dry at the time of our assessment. As such, only a small fraction (15 percent) of the identified dams currently (as of June 2015) impound significant water (with surface areas greater than $1,000 \mathrm{~m}^{2}$; fig. 10B). However, it is likely that dams permeable during low flow periods will impound water when flows increase during the monsoon season. When this occurs, downstream communities should be made aware that small and rapid breaches could occur and that hazardous debris flows could move down the channel. Local inhabitants should be alert to (1) sudden water level changes in rivers (either up or down); and (2) sudden changes in river consistency (color or particle composition), because these could indicate impending debris flows.

The landslide dam in Langtang deserves special attention because it consists primarily of ice and was only partially breached at the time of our assessment (May 28, 2015). The Langtang River currently flows through an approximately 650-m-long ice tunnel beneath the surface of deposits from the Langtang debris avalanche. The ice tunnel can accommodate low-water flows without any upstream ponding. However, during the monsoon or periods of intense snowmelt, the ice tunnel will experience additional internal erosion and surface caving to accommodate increased flows. In either of these scenarios, large pieces of ice might break free posing a downstream hazard associated with mobilization of both ice and existing channel debris. If collapsed ice does not melt quickly, upstream ponding could occur, leading to formation of a potentially hazardous lake impoundment above the ice-clogged channel. 
Table 1. Locations and characteristics of select valley-blocking landslides.

\begin{tabular}{|c|c|c|c|c|c|c|c|c|}
\hline Landslide name ${ }^{1}$ & District & River & $\begin{array}{l}\text { Latitude of } \\
\text { landslide } \\
\text { dam } \\
\left({ }^{\circ} \mathrm{N}\right)\end{array}$ & $\begin{array}{l}\text { Longitude of } \\
\text { landslide } \\
\text { dam } \\
\left({ }^{\circ} \mathrm{E}\right)\end{array}$ & $\begin{array}{l}\text { Dam } \\
\text { volume } \\
\left(\mathrm{m}^{3}\right)\end{array}$ & $\begin{array}{l}\text { Dam } \\
\text { material } \\
\text { type }\end{array}$ & $\begin{array}{l}\text { Estimated } \\
\text { area of } \\
\text { impound- } \\
\text { ment }^{2} \\
\left(\mathrm{~m}^{2}\right)\end{array}$ & Assessment as of June 1, 2015 \\
\hline Baisari & Myagdi & Kali Gandaki & 28.4010 & 83.6000 & 300,000 & Rock/soil & 30,000 & $\begin{array}{l}\text { Overtopped, draining through channel, } \\
\text { lake remains. }\end{array}$ \\
\hline Humde0 & Manang & Marsyangdi & 28.6453 & 84.0795 & $\mathrm{n} / \mathrm{a}^{3}$ & Soil & 0 & No sign of previous dam \\
\hline Humde 1 & Manang & Marsyangdi & 28.6388 & 84.0994 & 35,000 & Soil & 1,000 & Constricts river, currently eroding \\
\hline Humde 2 & Manang & Marsyangdi & 28.6364 & 84.1082 & 30,000 & Soil & 2,000 & Constricts river, currently eroding \\
\hline Pisang 1 & Manang & Marsyangdi & 28.6284 & 84.1339 & 50,000 & Soil & 500 & Constricts river, currently eroding \\
\hline Pisang 2 & Manang & Marsyangdi & 28.6253 & 84.1360 & 105,000 & Soil & 3,500 & Constricts river, currently eroding \\
\hline Pisang 3 & Manang & Marsyangdi & 28.6126 & 84.1530 & $\mathrm{n} / \mathrm{a}^{3}$ & Soil & 0 & Mostly eroded \\
\hline Pokhari 1 & Gorkha & Ranrun & 28.1684 & 85.7548 & 6,000 & Rock/soil & 0 & Blocks river, draining through rock debris \\
\hline Pokhari 2 & Gorkha & Ranrun & 28.1762 & 84.7570 & 3,000 & Rock/soil & 200 & Blocks river, draining through rock debris \\
\hline Pokhari 3 & Gorkha & Ranrun & 28.1792 & 84.7517 & 1,000 & Rock/soil & 100 & Blocks river, draining through rock debris \\
\hline Thorje $^{4}$ & Gorkha & Tom (Dogar) & 28.5570 & 84.7950 & $\mathrm{n} / \mathrm{a}$ & $\mathrm{n} / \mathrm{a}$ & $\mathrm{n} / \mathrm{a}$ & $\mathrm{n} / \mathrm{a}$ \\
\hline Sirdibas & Gorkha & Ghatta & 28.3932 & 84.8730 & 15,000 & Soil/rock & 0 & Mostly eroded, drains through channel \\
\hline Dobhan & Gorkha & Dobhan & 28.2962 & 84.9143 & 10,000 & Rock & 0 & Blocks river, flowing through rock debris \\
\hline Rumchetbeshi 1 & Gorkha & Rumchet & 28.2583 & 84.9011 & 1,000 & Rock & 0 & $\begin{array}{l}\text { Constricts river, flowing through rock } \\
\text { debris }\end{array}$ \\
\hline Rumchetbeshi 2 & Gorkha & Rumchet & 28.2591 & 84.8999 & 3,000 & Rock & 0 & $\begin{array}{l}\text { Constricts river, draining through rock } \\
\text { debris }\end{array}$ \\
\hline Rumchetbeshi 3 & Gorkha & Rumchet & 28.2605 & 84.8974 & 1,000 & Rock & 0 & Constricts river, flowing through channel \\
\hline Machhakholagau & Gorkha & Miujet & 28.2218 & 84.8812 & 15,000 & Rock & 0 & Blocks river, flowing through rock debris \\
\hline Khanigau 1 & Gorkha & $\begin{array}{l}\text { Budhi Gandaki } \\
\text { Nadi (trib.) }\end{array}$ & 28.2000 & 84.8607 & 4,000 & Rock & 0 & Blocks river, flowing through rock debris \\
\hline Khanigau 2 & Gorkha & $\begin{array}{l}\text { Budhi Gandaki } \\
\text { Nadi (trib.) }\end{array}$ & 28.2004 & 84.8611 & 4,000 & Rock & 0 & Blocks river, flowing through rock debris \\
\hline
\end{tabular}




\begin{tabular}{|c|c|c|c|c|c|c|c|c|}
\hline Landslide name ${ }^{1}$ & District & River & $\begin{array}{l}\text { Latitude of } \\
\text { landslide } \\
\text { dam } \\
\left({ }^{\circ} \mathrm{N}\right)\end{array}$ & $\begin{array}{l}\text { Longitude of } \\
\text { landslide } \\
\text { dam } \\
\left({ }^{\circ} \mathrm{E}\right)\end{array}$ & $\begin{array}{l}\text { Dam } \\
\text { volume } \\
\left(\mathrm{m}^{3}\right)\end{array}$ & $\begin{array}{l}\text { Dam } \\
\text { material } \\
\text { type }\end{array}$ & $\begin{array}{l}\text { Estimated } \\
\text { area of } \\
\text { impound- } \\
\text { ment }^{2} \\
\left(\mathrm{~m}^{2}\right)\end{array}$ & Assessment as of June 1, 2015 \\
\hline Khanigau 3 & Gorkha & $\begin{array}{l}\text { Budhi Gandaki } \\
\text { Nadi (trib.) }\end{array}$ & 28.2020 & 84.8630 & 25,000 & Rock & 0 & Blocks river, flowing through rock debris \\
\hline Khanigau 4 & Gorkha & $\begin{array}{l}\text { Budhi Gandaki } \\
\text { Nadi (trib.) }\end{array}$ & 28.2024 & 84.8636 & 20,000 & Rock & 0 & Blocks river, flowing through rock debris \\
\hline Kashigau & Gorkha & $\begin{array}{l}\text { Budhi Gandaki } \\
\text { Nadi }\end{array}$ & 28.2011 & 84.8765 & 100,000 & Soil & 0 & Constricts river, flowing through channel \\
\hline Dhunchet & Gorkha & Richet & 28.1764 & 84.9205 & 500 & Rock & 100 & $\begin{array}{l}\text { Constricts river, draining through channel, } \\
\text { lake remains }\end{array}$ \\
\hline Shyamchet & Gorkha & Dundare & 28.1443 & 84.8775 & 500 & Rock & 50 & $\begin{array}{l}\text { Blocks river, flowing through rock debris, } \\
\text { lake remains }\end{array}$ \\
\hline Shyamran & Gorkha & Mantan & 28.1387 & 84.8507 & 30,000 & Soil/rock & 0 & $\begin{array}{l}\text { Constricts river, flowing through rock } \\
\text { debris }\end{array}$ \\
\hline Hindun & Dhading & Ilep & 28.1933 & 85.0708 & 1000 & Rock & 1,000 & $\begin{array}{l}\text { Constricts river, flowing through channel, } \\
\text { lake remains }\end{array}$ \\
\hline Pentisa & Dhading & Akhu & 28.1902 & 85.0704 & 7,000 & Rock & 700 & $\begin{array}{l}\text { Mostly eroded; additional upslope rock } \\
\text { debris could block river again }\end{array}$ \\
\hline Isimgau & Dhading & Akhu & 28.1700 & 85.0501 & 500 & Rock/soil & 500 & $\begin{array}{l}\text { Constricts river, flowing through channel, } \\
\text { lake remains }\end{array}$ \\
\hline Boran & Dhading & Akhu & 28.1671 & 85.0491 & 500 & Soil/rock & 700 & $\begin{array}{l}\text { Constricts river, flowing through channel, } \\
\text { lake remains }\end{array}$ \\
\hline Jersyet 1 & Dhading & Akhu & 28.0968 & 85.0094 & 500 & Soil & 1,000 & $\begin{array}{l}\text { Constricts river, flowing through channel, } \\
\text { lake remains }\end{array}$ \\
\hline Jersyet 2 & Dhading & Akhu & 28.0958 & 85.0101 & 1,000 & Soil & 1,000 & $\begin{array}{l}\text { Constricts river, flowing through channel, } \\
\text { lake remains }\end{array}$ \\
\hline Chogegau & Dhading & Akhu & 28.0873 & 85.0068 & 4,000 & Soil/rock & 1,000 & $\begin{array}{l}\text { Constricts river, flowing through channel, } \\
\text { lake remains }\end{array}$ \\
\hline Ghattekholagua & Rasuwa & Ghatte & 28.2646 & 85.3827 & 7,000 & Rock & 0 & $\begin{array}{l}\text { Constricts river, draining through rock } \\
\text { debris }\end{array}$ \\
\hline Rasuwagadhi & Rasuwa & $\begin{array}{l}\text { Bhote Koshi } \\
\text { Nadi }\end{array}$ & 28.2751 & 85.3773 & 10,000 & Rock/soil & 1,000 & $\begin{array}{l}\text { Constricts river, draining through channel, } \\
\text { lake remains }\end{array}$ \\
\hline Langtang & Rasuwa & Langtang & 28.2121 & 85.4991 & $2,000,000$ & $\begin{array}{l}\text { Ice/rock/ } \\
\text { soil }\end{array}$ & 0 & Draining through ice tunnel \\
\hline Rimche 1 & Rasuwa & Chandampari & 28.1631 & 85.4625 & 40,000 & Rock & 0 & $\begin{array}{l}\text { Constricts river, draining through rock } \\
\text { debris }\end{array}$ \\
\hline Rimche 2 & Rasuwa & Chandampari & 28.1635 & 85.4479 & 40,000 & Rock & 0 & $\begin{array}{l}\text { Constricts river, draining through rock } \\
\text { debris }\end{array}$ \\
\hline
\end{tabular}




\begin{tabular}{|c|c|c|c|c|c|c|c|c|}
\hline Landslide name ${ }^{1}$ & District & River & $\begin{array}{l}\text { Latitude of } \\
\text { landslide } \\
\text { dam } \\
\left({ }^{\circ} \mathrm{N}\right)\end{array}$ & $\begin{array}{l}\text { Longitude of } \\
\text { landslide } \\
\text { dam } \\
\left({ }^{\circ} \mathrm{E}\right)\end{array}$ & $\begin{array}{c}\text { Dam } \\
\text { volume } \\
\left(\mathrm{m}^{3}\right)\end{array}$ & $\begin{array}{l}\text { Dam } \\
\text { material } \\
\text { type }\end{array}$ & $\begin{array}{l}\text { Estimated } \\
\text { area of } \\
\text { impound- } \\
\text { ment }^{2} \\
\left(\mathrm{~m}^{2}\right)\end{array}$ & Assessment as of June 1, 2015 \\
\hline Bhimali & Rasuwa & $\begin{array}{l}\text { Trishuli Ganga } \\
\text { Nadi }\end{array}$ & 28.1080 & 85.2751 & 25,000 & Rock & 13,000 & $\begin{array}{l}\text { Constricts river, draining through channel, } \\
\text { lake remains }\end{array}$ \\
\hline Gogane & Rasuwa & $\begin{array}{l}\text { Trishuli Ganga } \\
\text { Nadi }\end{array}$ & 28.0857 & 85.2274 & 150,000 & Rock & 35,000 & $\begin{array}{l}\text { Constricts river, flowing through channel, } \\
\text { lake remains }\end{array}$ \\
\hline Mailun Dobhan & Rasuwa & Mailun & 28.0785 & 85.2024 & 1,000 & Rock & 100 & $\begin{array}{l}\text { Constricts river, draining through rock } \\
\text { debris, lake remains }\end{array}$ \\
\hline Palep & Rasuwa & $\begin{array}{l}\text { Trishuli Ganga } \\
\text { Nadi }\end{array}$ & 28.0526 & 85.2071 & 10,000 & Rock/soil & 5,000 & $\begin{array}{l}\text { Constricts river, draining through channel, } \\
\text { lake remains }\end{array}$ \\
\hline Temran & Rasuwa & $\begin{array}{l}\text { Trishuli Ganga } \\
\text { Nadi (trib.) }\end{array}$ & 28.0276 & 85.2052 & 5,000 & Rock & 0 & Blocks river, draining through rock debris \\
\hline Urkin Kangari & Sindhupalchok & Pemdan & 28.1164 & 85.5336 & 12,000 & Rock & 0 & Blocks river, draining through rock debris \\
\hline Melamchigau 1 & Sindhupalchok & Melamchi & 28.0751 & 85.5427 & 30,000 & Rock/soil & 300 & $\begin{array}{l}\text { Blocks river, draining through rock debris, } \\
\text { lake remains }\end{array}$ \\
\hline Melamchigau 2 & Sindhupalchok & $\begin{array}{l}\text { Melamchi } \\
\text { (trib.) }\end{array}$ & 28.0742 & 85.5324 & 20,000 & Rock/soil & 300 & $\begin{array}{l}\text { Blocks river, draining through rock debris, } \\
\text { lake remains }\end{array}$ \\
\hline Melamchigau 3 & Sindhupalchok & Melamchi & 28.0413 & 85.5333 & 1,000 & Rock & 50 & $\begin{array}{l}\text { Constricts river, draining through channel, } \\
\text { lake remains }\end{array}$ \\
\hline Melamchigau 4 & Sindhupalchok & Melamchi & 28.0388 & 85.5327 & 1,000 & Rock & 400 & $\begin{array}{l}\text { Constricts river, draining through channel, } \\
\text { lake remains }\end{array}$ \\
\hline Melamchigau 5 & Sindhupalchok & Melamchi & 28.0344 & 85.5315 & 1,000 & Rock & 300 & $\begin{array}{l}\text { Constricts river, draining through channel, } \\
\text { lake remains }\end{array}$ \\
\hline Melamchigau 6 & Sindhupalchok & Namsan & 28.0488 & 85.5141 & 5,000 & Rock & 50 & $\begin{array}{l}\text { Constricts river, draining through channel, } \\
\text { lake remains }\end{array}$ \\
\hline Melamchigau 7 & Sindhupalchok & Namsan & 28.0442 & 85.5193 & 10,000 & Rock & 50 & $\begin{array}{l}\text { Blocks river, draining through rock debris, } \\
\text { lake remains }\end{array}$ \\
\hline Melamchigau 8 & Sindhupalchok & Namsan & 28.0417 & 85.5234 & 1,000 & Rock & 50 & $\begin{array}{l}\text { Blocks river, draining through rock debris, } \\
\text { lake remains }\end{array}$ \\
\hline Melamchigau 9 & Sindhupalchok & Namsan & 28.0392 & 85.5271 & 10,000 & Rock & 50 & $\begin{array}{l}\text { Blocks river, draining through rock debris, } \\
\text { lake remains }\end{array}$ \\
\hline Melamchigau 10 & Sindhupalchok & Namsan & 28.0352 & 85.5295 & 1,000 & Rock & 200 & $\begin{array}{l}\text { Constricts river, draining through channel, } \\
\text { lake remains }\end{array}$ \\
\hline Sunchaur & Sindhupalchok & Yangri & 28.0121 & 85.6018 & 8,000 & Rock & 1,000 & $\begin{array}{l}\text { Constricts river, draining through channel, } \\
\text { lake remains }\end{array}$ \\
\hline Singarchyat & Sindhupalchok & Larke & 28.0602 & 85.6551 & 500 & Rock & 0 & Mostly eroded \\
\hline
\end{tabular}




\begin{tabular}{|c|c|c|c|c|c|c|c|c|}
\hline Landslide name ${ }^{1}$ & District & River & $\begin{array}{l}\text { Latitude of } \\
\text { landslide } \\
\text { dam } \\
\left({ }^{\circ} \mathrm{N}\right)\end{array}$ & $\begin{array}{l}\text { Longitude of } \\
\text { landslide } \\
\text { dam } \\
\left({ }^{\circ} \mathrm{E}\right)\end{array}$ & $\begin{array}{c}\text { Dam } \\
\text { volume } \\
\left(\mathrm{m}^{3}\right)\end{array}$ & $\begin{array}{l}\text { Dam } \\
\text { material } \\
\text { type }\end{array}$ & $\begin{array}{l}\text { Estimated } \\
\text { area of } \\
\text { impound- } \\
\text { ment }^{2} \\
\left(\mathrm{~m}^{2}\right)\end{array}$ & Assessment as of June 1, 2015 \\
\hline $\begin{array}{l}\text { Hutunran } \\
\text { Bhanjyan }\end{array}$ & Sindhupalchok & Larke & 28.0030 & 85.6473 & 500 & Rock & 300 & $\begin{array}{l}\text { Constricts river, draining through channel, } \\
\text { lake remains }\end{array}$ \\
\hline Larcha & Sindhupalchok & Bhairavkund & 27.9419 & 85.9293 & 10,000 & Rock & 0 & $\begin{array}{l}\text { Constricts river, draining through channel, } \\
\text { no lake. }\end{array}$ \\
\hline Phulpin & Sindhupalchok & Khukundol & 27.9175 & 85.9354 & 8,000 & Soil/rock & 0 & $\begin{array}{l}\text { Constricts river, draining through channel, } \\
\text { no lake. }\end{array}$ \\
\hline Jhirpu & Sindhupalchok & $\begin{array}{l}\text { Bhote Koshi } \\
\text { Nadi }\end{array}$ & 27.9136 & 85.9244 & 2,000 & Rock/soil & 5,000 & $\begin{array}{l}\text { Constricts river, draining through channel, } \\
\text { lake remains }\end{array}$ \\
\hline Tusare & Sindhupalchok & Junrimba & 27.9075 & 85.9161 & 8,000 & Soil/rock & 0 & $\begin{array}{l}\text { Constricts river, draining through channel, } \\
\text { no lake. }\end{array}$ \\
\hline Chaku & Sindhupalchok & $\begin{array}{l}\text { Bhote Koshi } \\
\text { Nadi }\end{array}$ & 27.8784 & 85.9021 & 3,000 & Soil/rock & 5,500 & $\begin{array}{l}\text { Constricts river, draining through channel, } \\
\text { lake remains }\end{array}$ \\
\hline Lumnan & Dolakha & Lapche & 28.0251 & 86.1866 & 1,000 & Soil/rock & 500 & $\begin{array}{l}\text { Constricts river, draining through channel, } \\
\text { lake remains }\end{array}$ \\
\hline Lamabagar & Dolakha & Bhaise & 27.9011 & 86.2056 & 70,000 & Rock & 0 & Drains through rock debris. \\
\hline Rikhu & Dolakha & $\begin{array}{l}\text { Rolwalin } \\
\quad \text { (trib.) }\end{array}$ & 27.9020 & 86.3197 & 20,000 & Rock/soil & 0 & Drains through rock debris. \\
\hline Kutisyau & Dolakha & Sagu & 27.7897 & 86.1154 & 12,000 & Rock & 0 & $\begin{array}{l}\text { Constricts river, draining through debris, } \\
\text { no lake. }\end{array}$ \\
\hline Nanpol & Dolakha & Singati & 27.7670 & 86.1438 & 5,000 & Soil/rock & 1,500 & $\begin{array}{l}\text { Constricts river, draining through channel, } \\
\text { lake remains }\end{array}$ \\
\hline Gahate 1 & Dolakha & Bhurunga & 27.6222 & 85.9930 & 1,000 & Soil & 0 & $\begin{array}{l}\text { Constricts river, draining through channel, } \\
\text { no lake. }\end{array}$ \\
\hline Gahate 2 & Dolakha & Bhurunga & 27.6246 & 85.9871 & 2,000 & Soil & 0 & $\begin{array}{l}\text { Constricts river, draining through channel, } \\
\text { no lake. }\end{array}$ \\
\hline Thiwal & Kavrepalanchok & Khahare & 27.4939 & 85.7347 & 15,000 & Soil & 0 & River is currently dry. \\
\hline
\end{tabular}

${ }^{1}$ Name is generally labeled as the nearest village to the landslide.

${ }^{2}$ At the time of observation (May 27-June 1, 2015).

${ }^{3} \mathrm{n} / \mathrm{a}$ indicates that no estimate of landslide volume is possible due to erosion of the deposit

${ }^{4}$ The Thorje landslide was known from media reports to have formed a large landslide dam with lake but was not accessed during our reconnaissance and therefore only limited (satellite-imagery-based) assessment could be performed. 


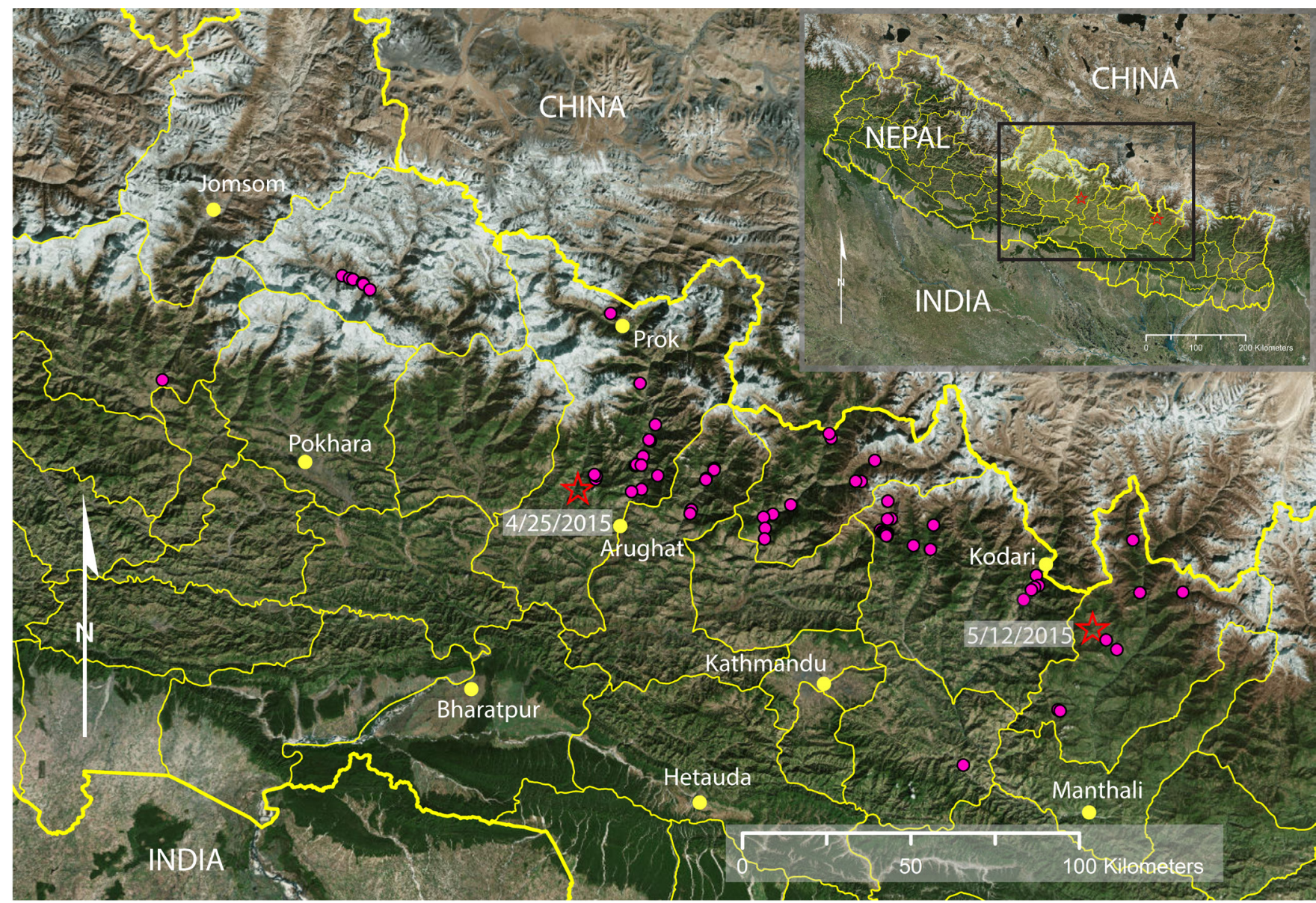

Figure 9. Regional map of central Nepal showing locations of valley-blocking landslides (pink dots) identified during helicopter- and satellite-based reconnaissance (see table 1). Some dots are obscured due to close proximity with other landslides. Major earthquake epicenters with dates are represented by red stars. Nepal district boundaries are indicated by yellow lines. Select city place names (yellow dots) are included for reference. 

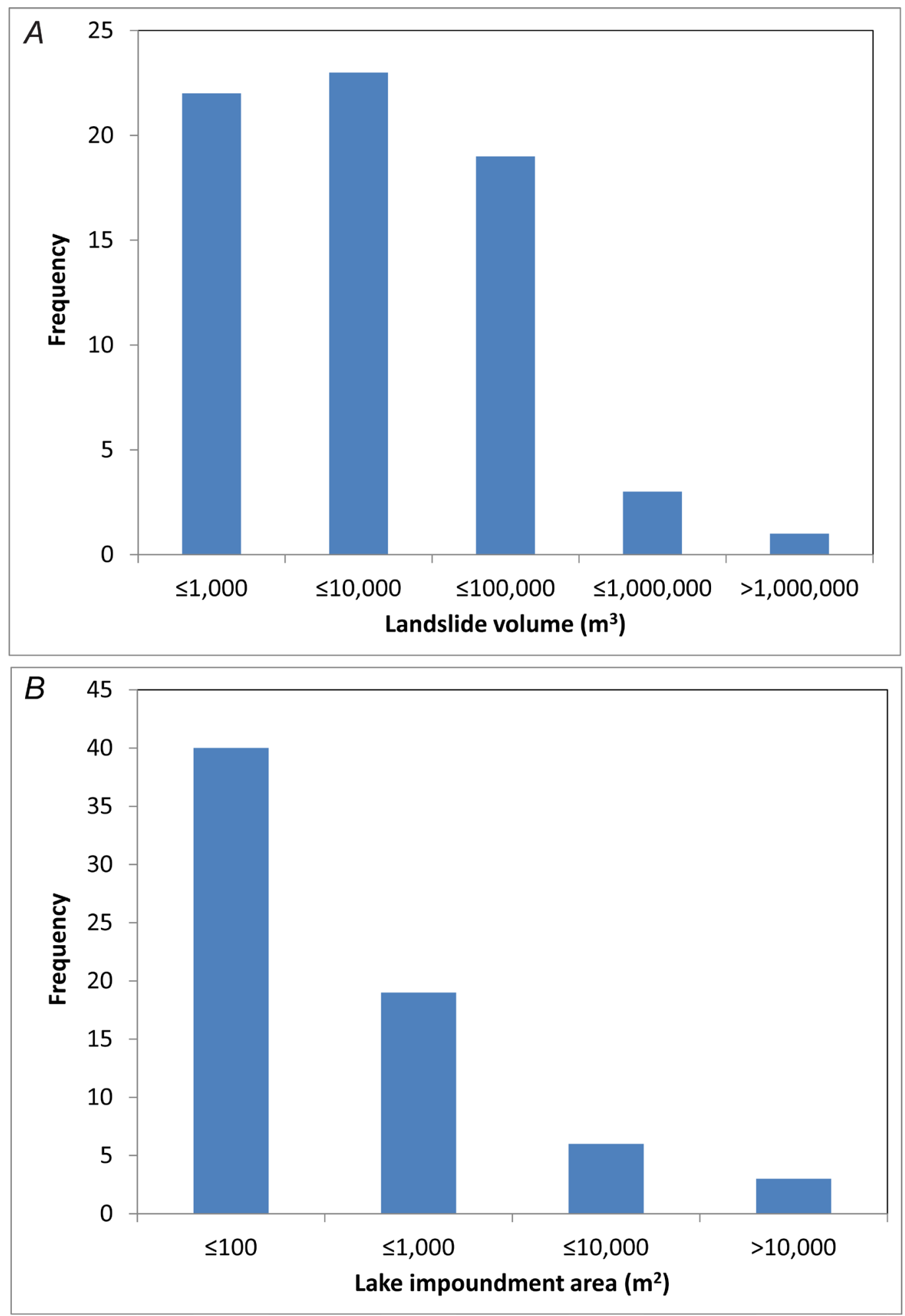

Figure 10. Histogram plots of valley-blocking landslide volume $(A)$ and valley-blocking landslide lake impoundment $(B)$ at the time of our assessment (May 27 to June 1, 2015), approximately one month following the main earthquake. Some dams without impoundments currently drain water through the dam debris or had dry rivers at the time of assessment. 


\section{Video Coverage of Select River Valleys}

Video coverage collected during travel to and from landslide assessment areas provides visual coverage of some of the most-devastated areas of Nepal resulting from the April and May 2015 earthquakes. Our video data totals over 11 hours, covering approximately 1,000 km of flight path (fig. 11). Due to limited data capacity and battery life, video coverage was not collected for all flight paths only those outlined in figure 11. All videos are available for download at http://dx.doi.org/10.5066/F7X928BN (see appendix 1 for organization of file names). In addition, a Google Earth .kmz file (appendix 1) provides georeferencing information that can be used to locate features within the video files. Video coverage of particular landslide areas resulting from the earthquake includes the following (listed as a filename at a particular time within that file):

- Tsho Rolpa moraine dam (Dolakha district)-USGS_Nepal_05272015-B@11:29

- 2014 landslide dam on the Sun Koshi River (Sindhupalchok district) - USGS_Nepal_05272015I@2:13

- Kodari area (Sindhupalchok district)-USGS_Nepal_05272015-J @2:10

- Kyanjin Gompa village (Rasuwa district) - USGS_Nepal_05282015-A@22:18

- Langtang debris avalanche (Rasuwa district)-USGS_Nepal_05282015-B@6:21

- Barpak village (Gorkha district) - USGS_Nepal_05282015-G-G @2:39

- Baisari rock slide and landslide dam (Myagdi district) - USGS_Nepal_05292015-A @19:23

- Prithvi Highway - Mugling to Thimura (Tanahu \& Chitwan districts) USGS_Nepal_05292015-C and -D

- Marsyangdi River earth slides near Humde and Pisang (Manang district) USGS_Nepal_05302015-A@4:08

- Pentisa landslide dam (Dhading district) - USGS_Nepal_05302015-I @20:38

- Kerauja rock slide (Gorkha district) - USGS_Nepal_06012015-E@1:50 


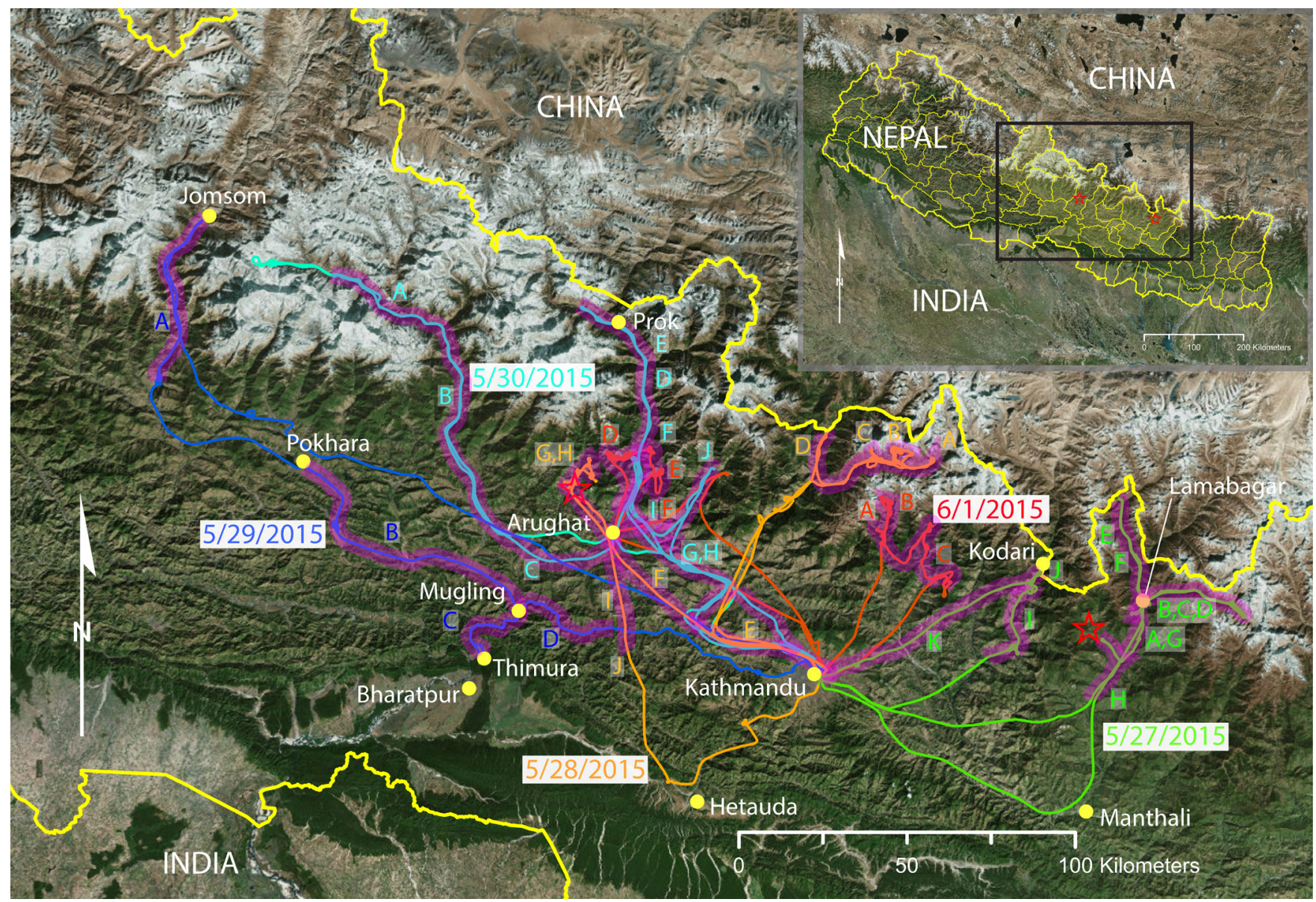

Figure 11. Regional map of Nepal showing helicopter flight path lines (colored lines) and areas (purple-shaded zones) where video coverage was collected. Color of alphabetical labels (A, B, C, and so forth) coincides with color of flight path lines with corresponding date labels. See appendix 1 for more information. Major earthquake epicenters with dates are represented by red stars. Select city place names (yellow dots) are included for reference. 


\section{Hazard Assessment of Selected Areas}

Although the earthquake triggered landslides throughout much of Nepal, we focused our attention on those that pose continuing hazard to downslope or downstream villages. Hundreds of such landslides probably resulted from the earthquakes; in fact, in any given year, landslides pose a serious hazard in Nepal, especially during summer monsoon rains (Petley and others, 2007). Analysis of landslide data between 1978 and 2005 indicates that an average of 78 fatalities occur as a result of landslides per year, but that the rate is dependent on monsoonal climatic conditions (Petley and others, 2007). In light of these statistics, we present hazard assessments of several select areas that warrant specific attention. We evaluated 5 areas of landsliding using helicopter-only assessments (due to a lack of safe landing zones) and 12 landslide areas using both helicopter- and ground-based assessments (table 2; fig. 8). We note that this list is far from comprehensive and only summarizes the level of effort that we could achieve over our short (5-day) assessment period. Whereas some landslides were assessed because of the high potential for ongoing hazard, others were investigated opportunistically as a result of helicopter routing and refueling logistics. For each landslide area, we provide pertinent details (location, landslide type, volume) along with a qualitative description of existing hazard. More detailed assessments for five of the landslides (Baisari landslide dam, Marsyangdi Valley landslide dams, Kerauja rock slide, Langtang debris avalanche, Tsho Rolpa moraine dam) are presented in the subsequent sections. 
Table 2. Locations and characteristics of landslides where site-specific assessments were performed.

[*Denotes that landslide hazard was only investigated using helicopter-based assessment]

\begin{tabular}{|c|c|c|c|c|c|c|c|}
\hline $\begin{array}{l}\text { Landslide } \\
\text { name }^{1}\end{array}$ & District & $\begin{array}{l}\text { Latitude of } \\
\text { source } \\
\text { area }\left({ }^{\circ} \mathrm{N}\right)^{2}\end{array}$ & $\begin{array}{l}\text { Longitude } \\
\text { of source } \\
\text { area }\left({ }^{\circ} \mathrm{E}\right)^{2}\end{array}$ & $\begin{array}{l}\text { Landslide } \\
\text { type }\end{array}$ & $\begin{array}{l}\text { Estimated } \\
\text { landslide } \\
\text { volume } \\
\left(\mathrm{m}^{3}\right)\end{array}$ & Observed damage & Expected hazard of observed landslide ${ }^{3}$ \\
\hline Baisari & Myagdi & 28.4026 & 83.6017 & Rock slide & 300,000 & Destroyed village & $\begin{array}{l}\text { Potential for additional rock slide and blockage } \\
\text { of river and road. }\end{array}$ \\
\hline $\begin{array}{l}\text { Marsyangdi } \\
\text { Valley } \\
\text { (Humde } 1 \& 2 \text { ) }\end{array}$ & Manang & $\begin{array}{l}28.6388 \\
28.6364\end{array}$ & $\begin{array}{l}84.0994 \\
84.1082\end{array}$ & Earth slides & $\begin{array}{l}35,000 \\
30,000\end{array}$ & none & $\begin{array}{l}\text { * Potential for additional blockage of river but } \\
\text { size of landslides limited by progressive failure } \\
\text { of river banks. }\end{array}$ \\
\hline $\begin{array}{l}\text { Marsyangdi } \\
\text { Valley } \\
\text { (Pisang } 1 \text { \& } 2)\end{array}$ & Manang & $\begin{array}{l}28.6284 \\
28.6253\end{array}$ & $\begin{array}{l}84.1339 \\
84.1360\end{array}$ & Earth slides & $\begin{array}{l}50,000 \\
105,000\end{array}$ & none & $\begin{array}{l}\text { *Potential for additional blockage of river but } \\
\text { size of landslides limited by progressive failure } \\
\text { of river banks. }\end{array}$ \\
\hline $\begin{array}{l}\text { Prithvi } \\
\text { Highway }\end{array}$ & $\begin{array}{l}\text { Tanahu and } \\
\text { Chitwan }\end{array}$ & 27.8210 & 84.4820 & Rock slides & ${ }^{4} 7,000$ & none & $\begin{array}{l}\text { * No large-scale landslides noted. Only minor } \\
\text { (background) additional landsliding expected } \\
\text { with rainfall. }\end{array}$ \\
\hline Barpak & Gorkha & 28.2003 & 84.7455 & $\begin{array}{l}\text { Ridgetop } \\
\text { shattering }\end{array}$ & 1,000 & Ground cracks & $\begin{array}{l}\text { Ground cracks could cause shallow landsliding } \\
\text { beneath steep southeast ridgeline. }\end{array}$ \\
\hline Kerauja & Gorkha & 28.2340 & 84.9120 & Rock slide & 250,000 & $\begin{array}{l}\text { Destroyed } \\
\text { pastures, } \\
1 \text { fatality }\end{array}$ & $\begin{array}{l}\text { Potential for rock falls but overall rock mass } \\
\text { appears stable. }\end{array}$ \\
\hline Pentisa & Dhading & 28.1908 & 85.0683 & Rock fall & 7,000 & $\begin{array}{l}\text { Blocked river, } \\
\text { killed livestock }\end{array}$ & $\begin{array}{l}\text { Unstable rock mass at source area and within } \\
\text { deposit could dam river again and currently } \\
\text { blocks trail to outside villages. }\end{array}$ \\
\hline Langtang & Rasuwa & 28.2330 & 85.4950 & $\begin{array}{l}\text { Debris } \\
\text { avalanche }\end{array}$ & $2,000,000$ & $\begin{array}{l}\text { Destroyed village, } \\
100+\text { fatalities }\end{array}$ & $\begin{array}{l}\text { Potential for rock falls, settlement of debris } \\
\text { deposit and impoundment of river from ice } \\
\text { tunnel collapse. }\end{array}$ \\
\hline Kyanjin Gompa & Rasuwa & ${ }^{5} 28.2120$ & ${ }^{5} 85.5670$ & $\begin{array}{l}\text { Snow } \\
\text { avalanche }\end{array}$ & $\mathrm{n} / \mathrm{a}^{5}$ & Destroyed village & $\begin{array}{l}\text { Additional potential for snow avalanches, but } \\
\text { other landslide hazards are minor (rock fall). }\end{array}$ \\
\hline $\begin{array}{l}\text { Urkin Kangari } \\
\text { Valley }\end{array}$ & Sindhupalchok & 28.0990 & 85.5420 & Rock fall & 500,000 & None & $\begin{array}{l}\text { Additional expected rock fall but no development } \\
\text { in area. }\end{array}$ \\
\hline Melamchigau & Sindhupalchok & 28.0195 & 85.5283 & $\begin{array}{l}\text { Ridgetop } \\
\text { shattering }\end{array}$ & 1,000 & Ground cracks & $\begin{array}{l}\text { Edge of village at cliff may undergo shallow } \\
\text { landslides but little danger to structures or } \\
\text { inhabitants. }\end{array}$ \\
\hline
\end{tabular}




\begin{tabular}{|c|c|c|c|c|c|c|c|}
\hline $\begin{array}{l}\text { Landslide } \\
\text { name }^{1}\end{array}$ & District & $\begin{array}{l}\text { Latitude of } \\
\text { source } \\
\text { area }\left({ }^{\circ} \mathrm{N}\right)^{2}\end{array}$ & $\begin{array}{l}\text { Longitude } \\
\text { of source } \\
\text { area }\left({ }^{\circ} \mathrm{E}\right)^{2}\end{array}$ & $\begin{array}{l}\text { Landslide } \\
\text { type }\end{array}$ & $\begin{array}{c}\text { Estimated } \\
\text { landslide } \\
\text { volume } \\
\left(\mathrm{m}^{3}\right)\end{array}$ & Observed damage & Expected hazard of observed landslide 3 \\
\hline Thanpalkot & Sindhupalchok & 27.9170 & 85.7000 & Earth flow & $3,000,000$ & None & $\begin{array}{l}\text { * Debris flows from surface of earth flow likely to } \\
\text { be contained in existing channels. }\end{array}$ \\
\hline Kodari & Sindhupalchok & 27.9710 & 85.9610 & Rock falls & $\begin{array}{l}\text { Many: } \\
\qquad \begin{array}{l}100- \\
1,000\end{array}\end{array}$ & $\begin{array}{l}\text { Destroyed } \\
\text { buildings, } \\
\text { roads; fatalities }\end{array}$ & $\begin{array}{l}\text { Potential for reactivation of rock falls and } \\
\text { shallow landslides. }\end{array}$ \\
\hline Guna Gadhi & Sindhupalchok & 27.9163 & 85.9176 & $\begin{array}{l}\text { Ridge top } \\
\text { shattering }\end{array}$ & $\begin{array}{l}\text { Many: } \\
1,000- \\
10,000\end{array}$ & Ground cracks & $\begin{array}{l}\text { Entire mountain is highly fractured and rock } \\
\text { slides and debris flows are likely into river and } \\
\text { nearby hydroelectric plant. }\end{array}$ \\
\hline Sun Koshi & Sindhupalchok & 27.7700 & 85.8685 & Rock slide & $\begin{array}{l}\text { Several: } \\
100\end{array}$ & $\begin{array}{r}\text { Minor road } \\
\text { blockage }\end{array}$ & $\begin{array}{l}\text { *Potential for additional rock falls from source } \\
\text { area; major slide feature appears stable. }\end{array}$ \\
\hline Simigau & Dolakha & 27.8730 & 86.2310 & $\begin{array}{l}\text { Ridge top } \\
\text { shattering }\end{array}$ & 500 & Ground cracks & $\begin{array}{l}\text { Sides of ridgetop are unstable and have potential } \\
\text { for shallow landslides. }\end{array}$ \\
\hline Tsho Rolpa & Dolakha & 27.8692 & 86.4630 & $\begin{array}{l}\text { Lateral } \\
\text { spread }\end{array}$ & 2,500 & Ground cracks & $\begin{array}{l}\text { Lateral spread appears decoupled from overall } \\
\text { stability of moraine dam. }\end{array}$ \\
\hline
\end{tabular}

${ }^{1}$ Name is generally labeled as the village or geographic feature nearest to the landslide.

${ }^{2}$ Locations provided in fig. 8.

${ }^{3}$ At the time of observation (May 27-June 1, 2015).

${ }^{4}$ Volume is the total estimate from four shallow landslides noted over approximately $100 \mathrm{~km}$ of the highway between Thimura, Mugling, and Kathmandu.

${ }^{5}$ Coordinates are of the affected village rather than the source area - the avalanche came from the north but its source area is not known precisely. A volume estimate is not possible because the deposit had melted away prior to our assessment.

${ }^{6}$ Assessment does not include potential landslides into the moraine dammed lake or potential subsequent catastrophic failure of the dam itself. 


\section{Baisari Landslide Dam (Kali Gandaki River, Myagdi District)}

On May 24, 2015, twenty-nine days after the $M 7.8$ main shock, a rock slide approximately 350 m-long, 200-m-wide, and 4-m-deep mobilized from a cliff, blocked the Kali Gandaki River in Myagdi district, and buried the village of Baisari (fig. 8) under about $30 \mathrm{~m}$ of debris (fig. 12). According to interviews we conducted with Nepal Army personnel on May 29, 2015, cracks had formed in the cliff following the April 2015 M7.8 earthquake. The existing cracks widened during the M7.3 earthquake on May 12, 2015, and rocks began falling from the cliff 10 days later on May 22. As a result, the Nepal Army evacuated Baisari, and the cliff failed two days later at about 1:00 a.m. on May 24. The landslide destroyed 27 homes and buried the entire village under landslide debris. Damming of the river by the landslide caused upstream flooding and formation of a lake. Using a field-estimated landslide-dam height of $30 \mathrm{~m}$, and using a coarse (Google-Earth-derived) DEM (with estimated horizontal resolution of $30 \mathrm{~m}$ ) of the area to compute the length of upstream river that $30 \mathrm{~m}$ of inundation height would have created, we estimate the maximum inundation length to have been approximately $2.7 \mathrm{~km}$. We estimate the lake width to have been approximately $100 \mathrm{~m}$ given the geometry of the upstream gorge. Assuming a simplified geometry for the landslide dam lake and using a maximum depth of the landslide lake of about $30 \mathrm{~m}$ indicates that the lake would have impounded $\sim 8,000,000 \mathrm{~m}^{3}$ of water. The lake overtopped the dam 16 hours after it formed and sent a flood-wave down the Kali Gandaki River; water levels reportedly rose temporarily to $2 \mathrm{~m}$ above normal monsoon flood stage. Fortunately, communities downstream from the landslide dam had been evacuated, and no loss of life occurred. At the time of our investigation (May 29, 2015), landslide debris still partially blocked the river, and a lake approximately 1,200 $\mathrm{m}$ long and $25 \mathrm{~m}$ wide still blocked road access upstream (fig. 13).

This landslide probably was in an incipient state of instability prior to the earthquake. Earthquake shaking likely initiated additional movement along or across pre-existing fractures, and this deformation progressed gradually in the days following the earthquake until failure occurred. Few other landslides were triggered in this general area, which suggests that the site of this slide was rendered unstable by oversteepening of the slope by fluvial erosion. The cliff face immediately south of the landslide scar is quite steep $\left(>70^{\circ}\right)$, and although vegetated, it appears to be the site of former rock slides and rock falls. Despite this, interviews with elder villagers conducted on May 29, 2015 indicated that no prior significant landsliding was known to have occurred at this location during their lifetime, nor that of their parents (a period of perhaps $100 \mathrm{yr}$ ).

We estimate the volume of the rock slide to be $300,000 \mathrm{~m}^{3}$ based on field approximations of the dimensions of the deposit (200 m long, $50 \mathrm{~m}$ wide, and $30 \mathrm{~m}$ deep) and the previously described failure geometry. The cliff is composed of a metamorphic assemblage of slate and phyllite, and despite the hardness and apparent strength of the rocks in the near-vertical source area, the rock slide disaggregated to form a debris deposit with few rocks larger than $1 \mathrm{~m}$ in longest dimension and a mean grain size of less than $20 \mathrm{~cm}$. At the time of our investigation, the surface of the deposit was covered with about 30 $\mathrm{cm}$ of fine silt - presumably an airfall deposit resulting from failure of the dry rock slide.

Overall, we judged this area to have high landslide hazard based on both continuing rock fall from the source area (approximately $100 \mathrm{~m}^{3}$ fell during our assessment on May 29, 2015; fig. 14) and also the presence of a large wedge of intact cliff just north of the recent scarp that is surrounded by landslide scars (fig. 12). This wedge, which is about the same volume as the recent rock slide, is bounded by a debris slide to the north and the rock slide scar on the south; these observations indicate that additional landsliding could occur in this area. If this wedge fails entirely, its volume would likely be sufficient to completely block the Kali Gandaki River again. 

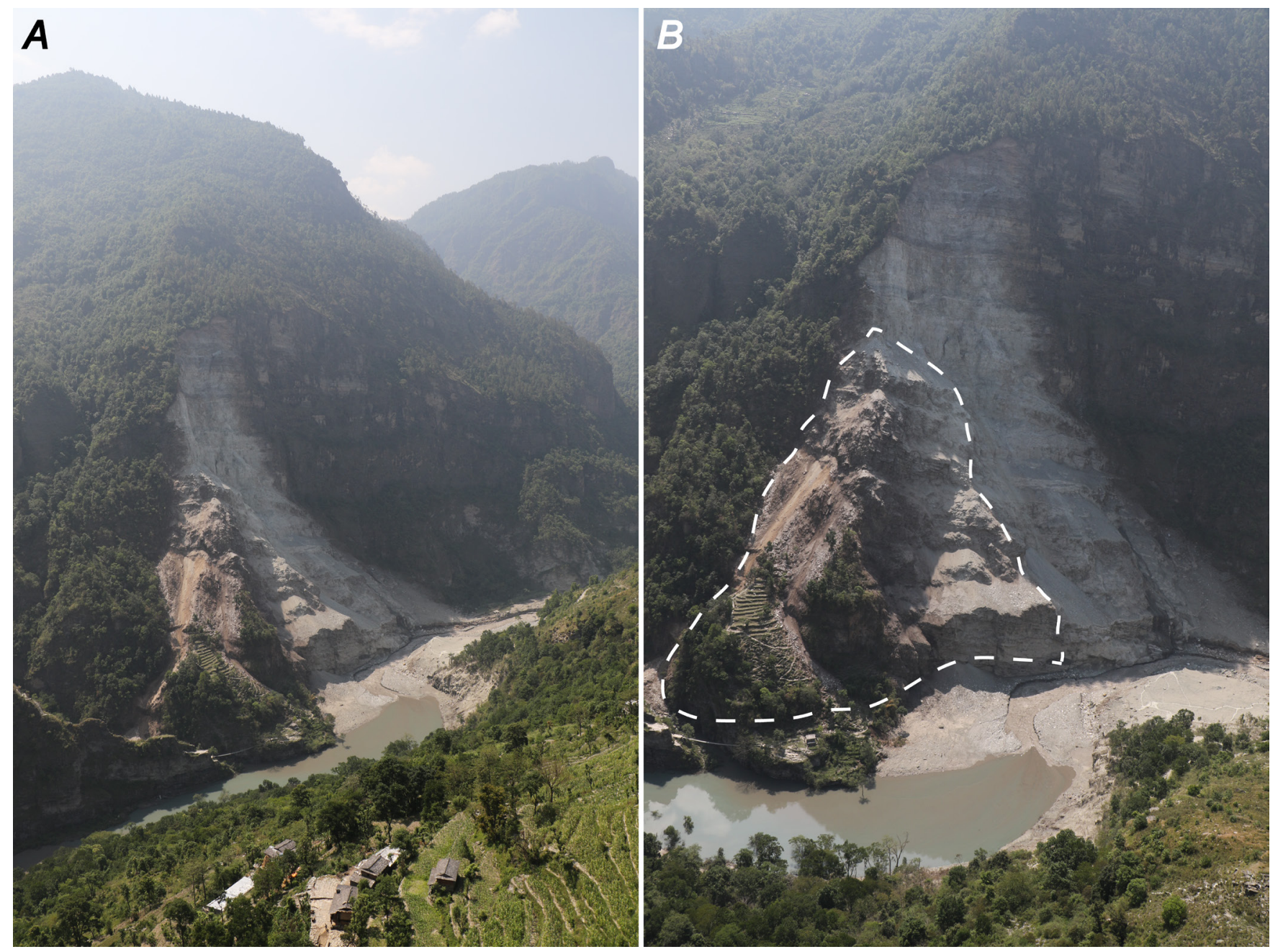

Figure 12. Photographs showing rock slide along the Kali Gandaki River on May 24, 2015 that buried the village of Baisari and blocked the flow of the river for 16 hours nearly one month following the main earthquake shock $(A$, $B$ ). Progressive failure of the nearly $350-\mathrm{m}$-tall rock mass through the weathered bedrock profile is thought to have led to its eventual collapse. $B$, Wedge area of future potential instability is outlined by white dashed line. 


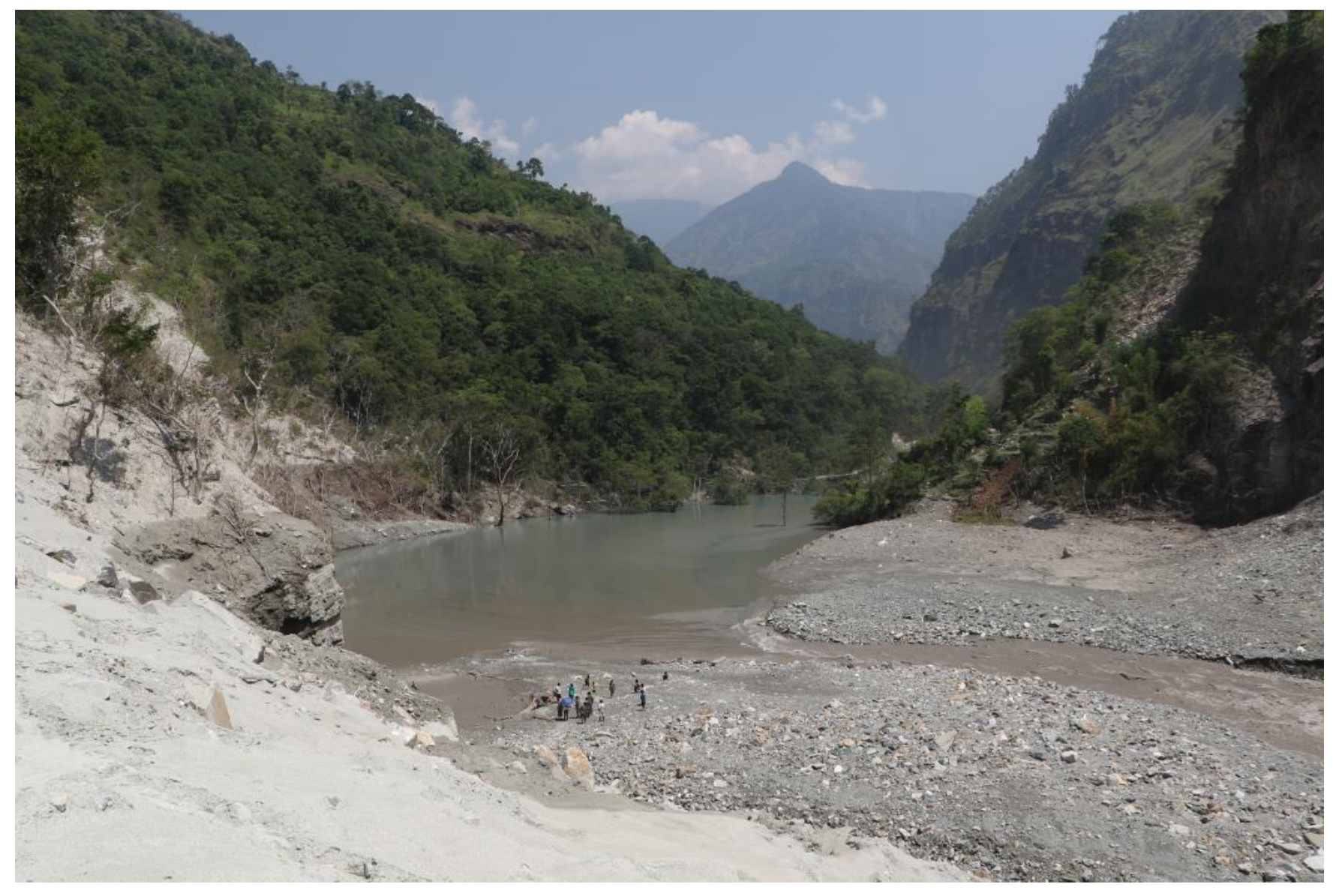

Figure 13. Photograph showing existing lake impoundment formed by May 24, 2015 rock slide at Baisari village. The lake blocks road access to all villages to the north. 


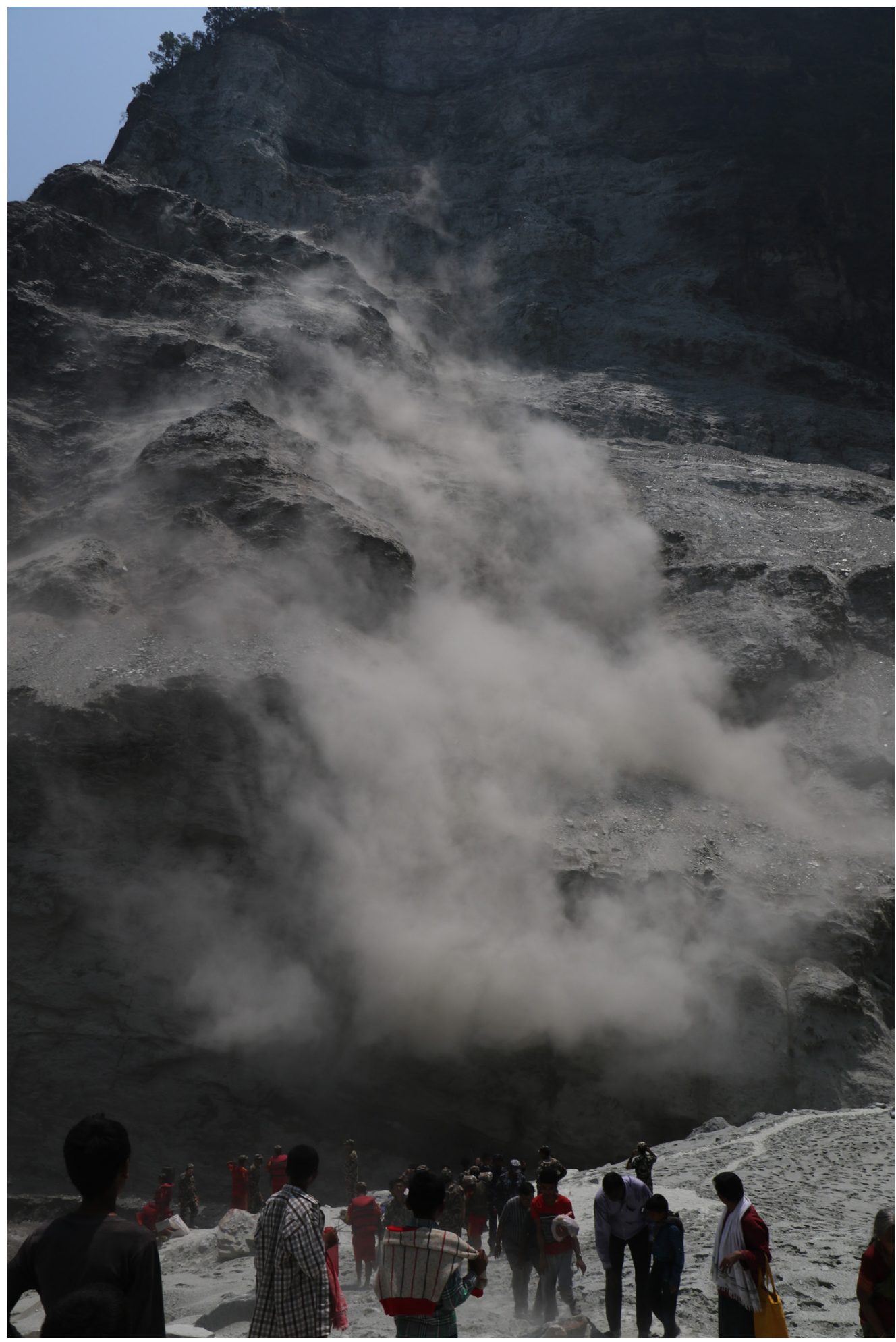

Figure 14. Photograph showing rock fall from landslide scarp (as expressed by dust cloud) five days after the failure, indicates continuing hazard in the Baisari area. 


\section{Marsyangdi Valley Landslide Dams (Marsyangdi River, Manang District)}

The Marsyangdi River Valley (also known as Manang Valley) is located north of the Annapurna Himal and forms a roughly $50-\mathrm{km}$-long valley surrounded by peaks $6,000-8,000 \mathrm{~m}$ in elevation. Several landslides either completely or partially blocked the flow of the Marsyangdi River between the villages of Pisang and Humde (located roughly at the halfway point through the valley; fig. 8); we discuss these as examples of landslide dams that breached naturally and without incident.

Upstream from the village of Pisang, we assessed two landslides (Pisang $1 \& 2$; table 2) that mobilized from the north side of the river. Further upstream, near the village of Humde, we assessed two additional landslides (Humde $1 \& 2$; table 2), which also initiated from the north bank of the river. All of these slides constricted the river; at least two (Pisang 2 and Humde 1) showed signs of previously having completely blocked the river. According to a local inhabitant, an additional landslide located just upstream from the Manang Airport also blocked the river for five days before breaching without incident. Our reconnaissance did not identify the exact location of this former landslide dam although we did identify an area of slackwater that may represent the remains of a dammed lake. We saw several other landslides (see supplemental video files for 5/30/2015) near and downstream from Pisang of similar character but smaller size, with consequently less constriction to the river.

The majority of river-bank material in the area in which these landslides occurred appears to be fine grained; the lack of boulder-size material might allow rapid erosion of debris. The material is likely weakly lithified glacio-fluvial sediment (mapped in this area by Weidinger, 2006). However, some parts of the banks might also be composed of a rock-avalanche deposit first identified by Hagen (1968) and subsequently confirmed by detailed mapping by both Weidinger (2006) and Fort (2011). Motion of the recent landslides was primarily translational with a small component of rotation. Given the fine-grain material making up the deposits, we classified these landslides as earth slides. Some of the slides also had a flow component to their motion as suggested by flow lines on the surface of debris cones and the spreading nature of the deposit at river's edge. We observed shallow lakes and streams in the vicinity of the river at the time of our assessment; this indicated that the ground could have been near saturation at the time of the earthquakes. This, along with potential entrainment of the river, would have facilitated some earth slides transitioning into flows.

Our estimates of landslide volumes range from 30,000 to $100,000 \mathrm{~m}^{3}$. At the Pisang 1 landslide, partial blockage of the river currently (May 30, 2015) formed a 50-m-long slackwater lake upstream of the constriction. At Pisang 2 (fig. 15), an approximately 350-m-long lake had formed with surface elevation that we estimate from drowned trees to be about $3 \mathrm{~m}$ above pre-slide river levels. This landslide is reported to have completely blocked the flow of the river and formed a longer lake that subsequently breached when water spilled over the top of the landslide dam. The river course is now against the south side of the river channel and continues to erode the landslide toe. The Humde 1 landslide (fig. 16A) also likely fully blocked the river's flow. It currently backs up water for approximately $100 \mathrm{~m}$ with an estimated river-surface elevation increase of $1 \mathrm{~m}$. Similarly, the Humde 2 landslide (fig. 16B) backs up water for about $200 \mathrm{~m}$ with an estimated river-surface elevation increase of $1 \mathrm{~m}$ above pre-slide river elevations and also likely temporarily blocked the river's flow.

Based on several existing constrictions in the river from these landslides, we judge the hazard level of these landslides to be moderate and expect that additional landslide deformation will occur from fluvial erosion at the toe of the landslide. If deposits remobilize as flows, they could impound the river again. If the volume of a river-blocking deposit is small, it could be quickly overtopped and eroded away similar to what occurred in the days and weeks following the earthquake. However, if a larger deposit forms, this could impound significant volumes of water, and given the fine grain size of the deposit material, rapid and catastrophic breaching could occur. 


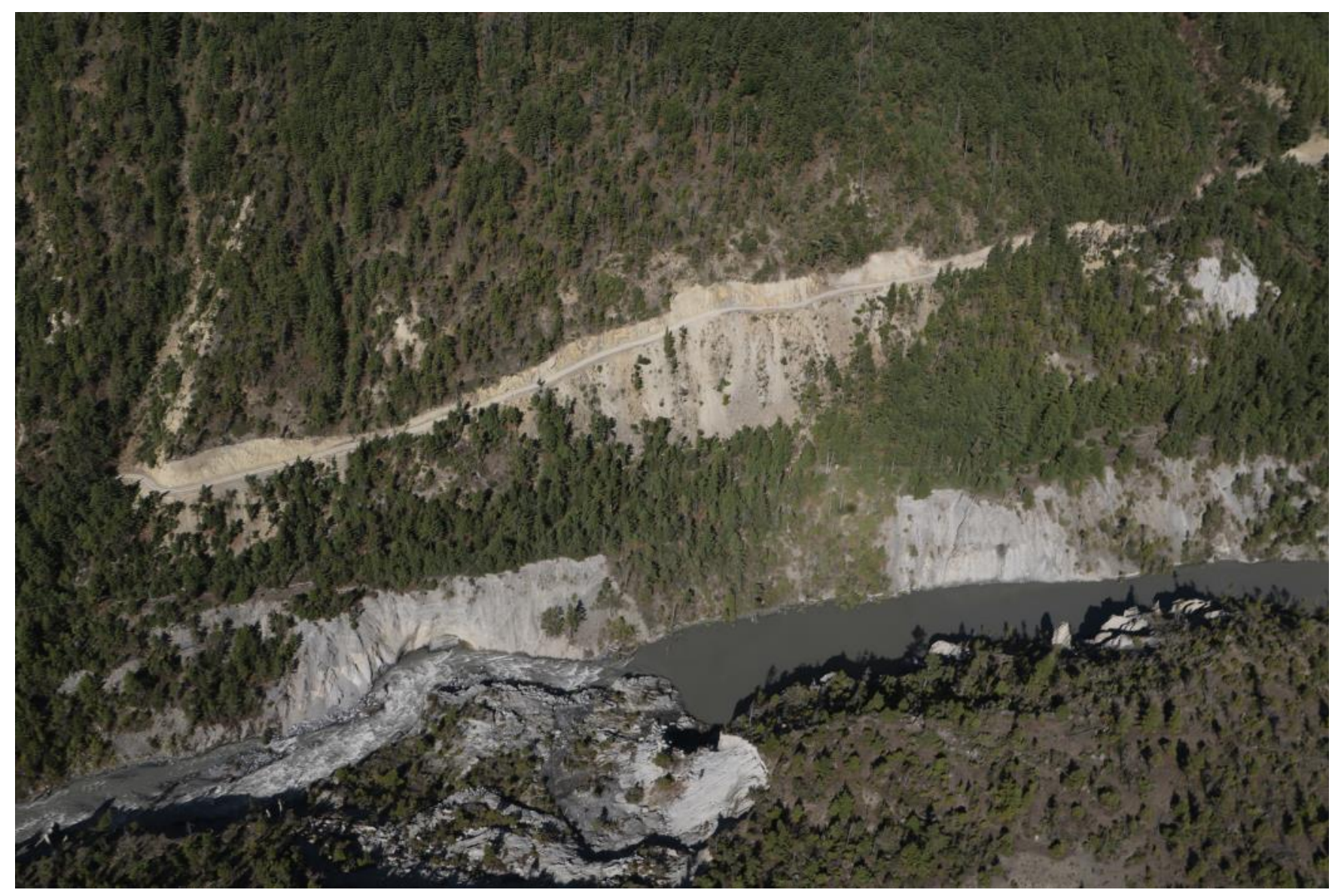

Figure 15. Aerial image of the Pisang 2 earth slide along the Marsyangdi River upstream from Pisang village. As of May 30, 2015, this landslide constricted the river with a 350-m-long slackwater lake upstream of the landslide deposit. Maximum width of impoundment in image is approximately $50 \mathrm{~m}$. 

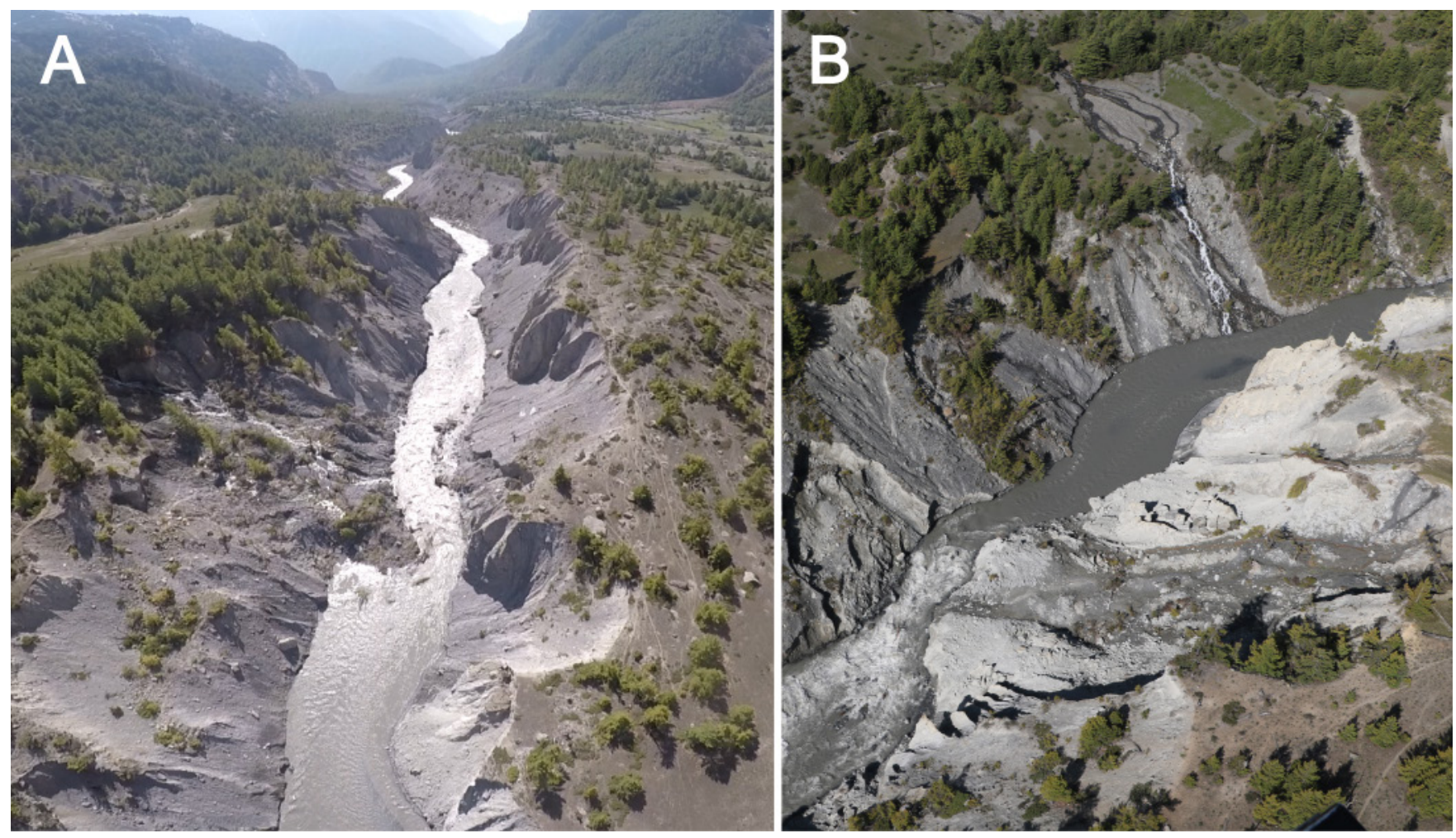

Figure 16. Aerial images of the Humde $1(A)$ and Humde $2(B)$ earth slides along the Marsyangdi River downstream from Humde village. Both landslides probably temporarily blocked the river's flow and as of May 30 , 2015 , had constricted the river to form slackwater lakes upstream of the landslides. Maximum width of impoundments shown in $A$ and $B$ is approximately $30 \mathrm{~m}$. 


\section{Kerauja Rock Slide (Budhi Gandaki River, Gorkha District)}

In Gorkha district, we investigated an approximately 500-m-long, 210-m-wide rock slide (fig. 17 and also report cover image) affecting the upper edge of Kerauja village (fig. 8). In this village, 70 percent $(\sim 400)$ of the homes were destroyed, and landslides and structural collapses were responsible for 11 fatalities. The major rock slide above the village killed 1 person and 80 sheep and continued to shed rocks even one month following the main shock. Similar to most other landslides that occurred during and immediately after the earthquakes, this failure appears to have initiated high on the slope (approximate elevation 2,630 m) near the ridge top. Based on indirect measurements made of the talus from available post-earthquake imagery, we estimate the volume of this failure to be $250,000 \mathrm{~m}^{3}$. Given an average scarp length and width of $300 \mathrm{~m}$ and $210 \mathrm{~m}$, respectively, we back-calculate the depth of the failure plane to be approximately $4 \mathrm{~m}$. This assessment is consistent with close-up observations of the main scarp, which showed that some vegetation remains on the slope and that the top of the slope has a fairly thin ( $\sim 3-\mathrm{m}$-thick) weathering profile. The rock in this area is predominantly quartzite (as interpreted from rocks identified in the village), and although the scarp has a significant degree of fracturing, the rock mass appeared to be fairly competent. According to villagers, this slope was vegetated prior to the earthquake, and no one recalled there having been previous landsliding or significant water seepage from this area.

Overall, we judged this rock slide to have a low hazard related to additional reactivation, other than small rock falls of perhaps hundreds to thousands of cubic meters that might be expected over the next year or more. Small debris flows could also initiate from higher talus slopes, but they are unlikely to reach the village. We saw some evidence of shallow debris flows from near the top of the talus, where presumably minor groundwater seepage mobilized loose, unconsolidated debris remaining on the failure scarp. An additional nearby landslide to the west of the main rock slide resulted in another fatality according to villagers, and our aerial reconnaissance indicated other smaller instabilities on the adjacent slopes. Although we did not observe any evidence of ridge-top cracking during low-level aerial investigation in the immediate areas adjacent to the main rock slide, additional rock falls from these slopes should be expected. 

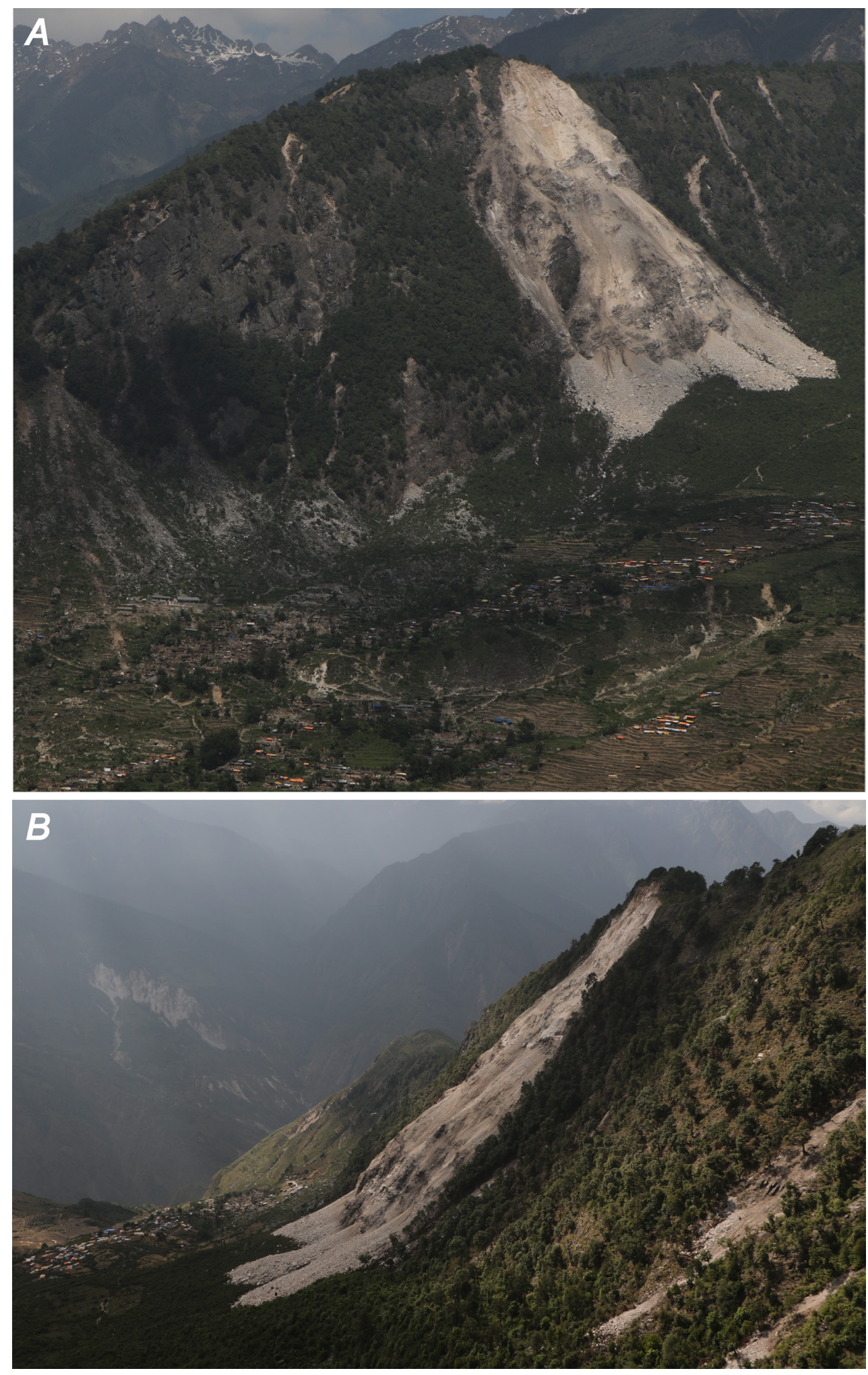

Figure 17. Photographs showing fatal rock slide above Kerauja village in Gorkha district $(A, B)$. Maximum bedrock scarp length is approximately $350 \mathrm{~m}$. Landslides from adjoining slopes to the northwest (left of main rock slide in $[A])$ resulted in one additional fatality. 


\section{Langtang Debris Avalanche (Langtang River, Rasuwa District)}

The largest and most destructive landslide triggered by the 2015 earthquakes was a debris avalanche (fig. 18) that destroyed the village of Langtang in the Langtang Valley of Rasuwa district (fig. 8). Although the exact location of the uppermost source is difficult to identify, the landslide appeared to initiate at an elevation above 5,000 $\mathrm{m}$ on the flank of Langtang Lirung, a 7,227-m-high peak on the north wall of the valley (fig. 19). Large masses of glacial ice broke loose from multiple source areas during the earthquake shaking, and as the ice rapidly descended the steep slopes above the valley it entrained a mixture of rock and soil from the ground surface and surrounding valley walls. The mixture of ice, rock, and soil accelerated down an approximately $35^{\circ}$ slope and then became at least partially airborne at a point $500 \mathrm{~m}$ above the valley floor where the slope steepens to about $50^{\circ}-55^{\circ}$.

Tragically, the landslide debris landed directly on Langtang village and completely destroyed it; the estimated number of fatalities exceeds 200. Most of the village is buried beneath the deposit; a few outlying structures on the east end of the village were not buried but were flattened by an accompanying air blast generated by the speed and volume of the debris avalanche. In addition to destroying several structures, the air blast completely flattened the forest for about $1 \mathrm{~km}$ in each direction up and down the valley as well as all the way up to tree line on the south (opposing) valley slope. Trees were stripped of branches and bark and were laid down in a radial pattern outward from the deposit (fig. 20).

The map distance from the crown of the landslide to the distal tip of the deposit was 3,700 m. The total vertical drop over that length was at least $1,850 \mathrm{~m}$. The deposit covered an area $400 \mathrm{~m}$ wide by $900 \mathrm{~m}$ long. A preliminary estimate of the total volume of the deposit (based on depth estimates in different parts of the deposit made during our ground investigation) is $2,000,000 \mathrm{~m}^{3}$. We estimate that more than half of the deposit was ice; the remainder was a mixture of soil and rock fragments in roughly equal proportion. The surface of the deposit was very wet, which suggests that ice was also on the surface of the deposit at the time of deposition but has since melted. The melting of surface ice has concentrated soil and rock fragments on the surface of the deposit, which is now fairly flat and uniform except for a $\sim 10$-m-high knoll of unknown origin near the center of the deposit. The toe of the deposit filled the inner gorge of the Langtang River, which was perhaps $15 \mathrm{~m}$ deep at this location; the landslide material came to a stop as far as $100 \mathrm{~m}$ up the opposing valley wall. The river apparently melted the ice that was deposited in the river channel and, at the time of our investigation (May 2015), was flowing through a tunnel in the ice and debris (fig. 21). Continued melting of the ice over the river could cause the tunnel to collapse, which might result in temporary blockages of the river.

Estimating the velocity of the landslide is challenging because of limited data. Such estimates generally are made using a simple equation of motion:

$$
v=(2 g h)^{0.5}
$$

where $v$ is the final velocity, $g$ is the acceleration of gravity $\left(9.8 \mathrm{~m} / \mathrm{s}^{2}\right), h$ is the total vertical distance, and the initial velocity is zero. One application of this equation is to estimate velocity based solely on the freefall (airborne) part of the travel path. If we conservatively neglect the initial velocity at the point where the slide became airborne and use the 500-m height of the lower cliff as the vertical distance, the final velocity at impact would be 99 meters per second $(\mathrm{m} / \mathrm{s})$. Another approach is to estimate velocity based on the run-up distance on the opposing valley slope; Chow (1959) proposed using equation 1 where $h$ is the run-up distance, and this method has been widely used for such estimates (Voight and Sousa, 1994; Evans and others, 2001; Jibson and others, 2004, 2006). At Langtang, run-up distances varied from about 25 to $100 \mathrm{~m}$ at different places along the valley wall. These run-ups indicate a range of velocities of $22-44 \mathrm{~m} / \mathrm{s}$. Taken together, these two approaches to velocity estimation suggest a range of 
22-99 m/s; this is consistent with velocity estimates of 36-93 m/s from other, similar landslides (Plafker and others, 1971; Voight and Sousa, 1994; Evans and others, 2001; Jibson and others, 2004, 2006).

In some areas, the surface of the deposit shows features suggesting fluid flow, such as braided deposits and flow banding. Such flow features are common on large, rapid landslides (Voight and Sousa, 1994; Jibson and others, 2004, 2006) and indicate that, even though these features consist of relatively coarse fragments of rock, soil, and ice, they behave as fluids when moving at high speed.
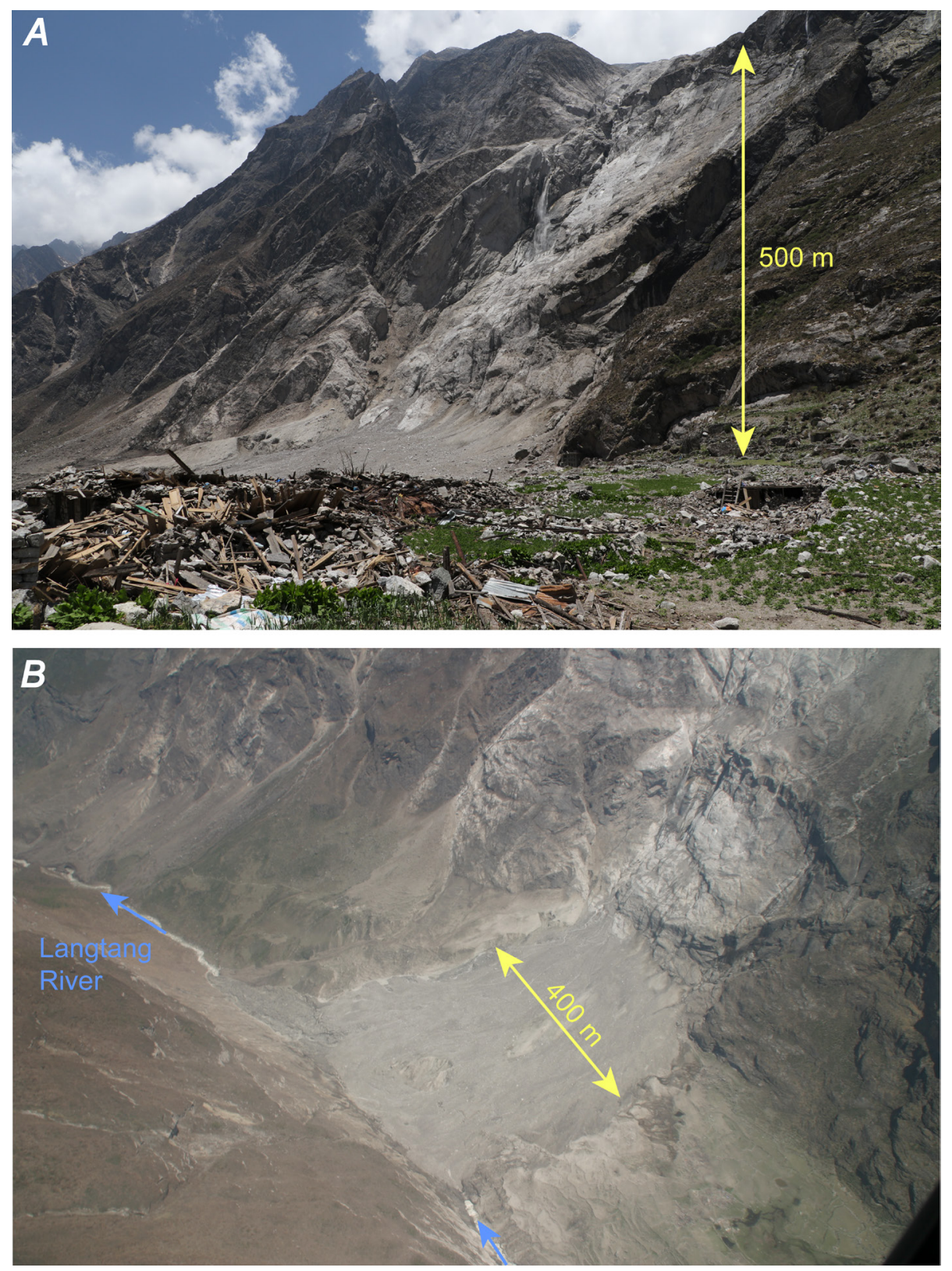

Figure 18. Photographs showing the Langtang debris avalanche, which destroyed the entire village of Langtang either through direct deposition or by consequent air blast. An estimated 200 people were killed in this single event. $A$, Oblique northwest view of deposit with cliff in which the debris became airborne. Homes in foreground were pushed over by the ensuing airblast. $B$, Aerial view of deposit showing location of the Langtang River tunnel through ice and debris (fig. 21). 


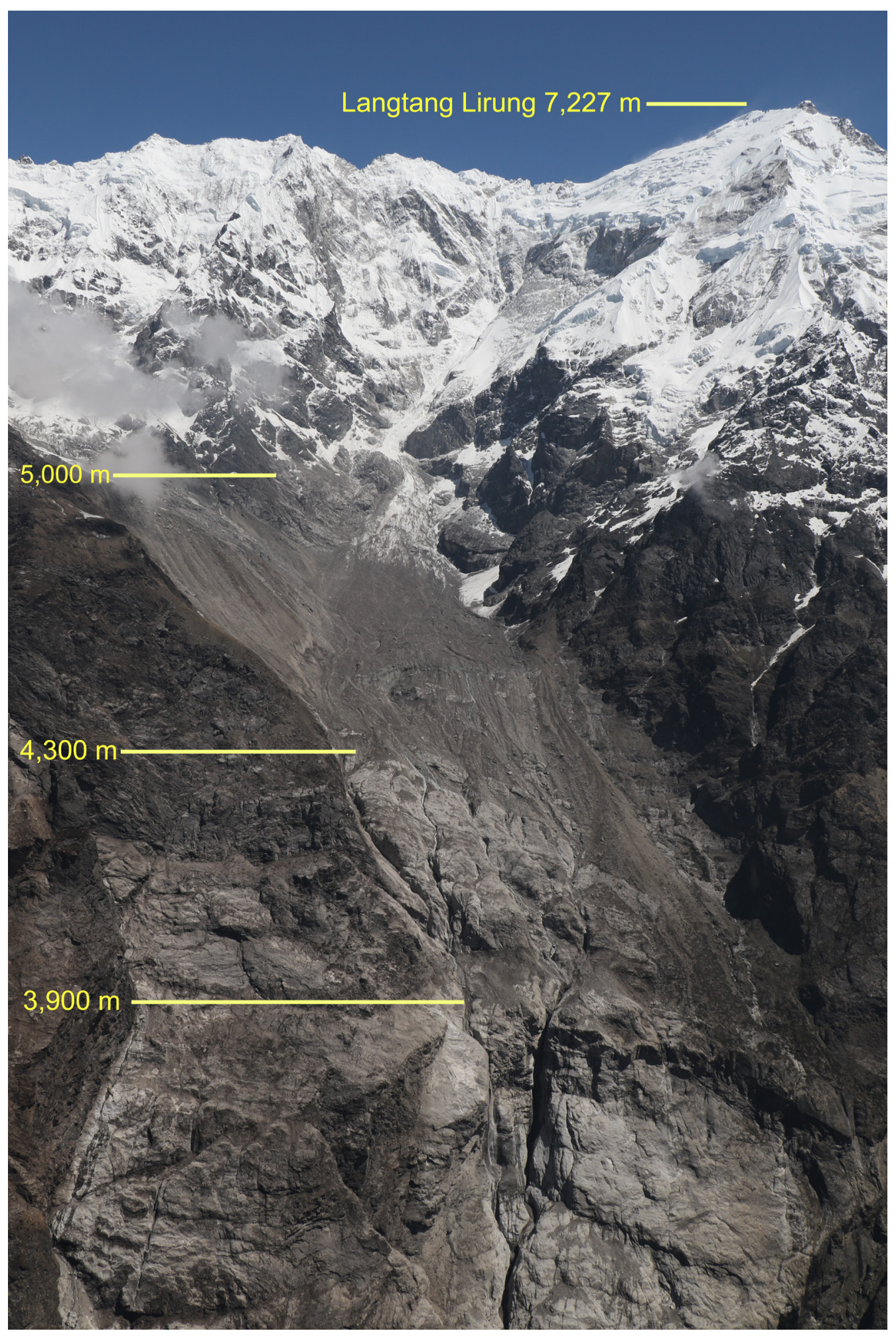

Figure 19. Photograph showing source area of Langtang debris avalanche was in ice slopes above $5,000 \mathrm{~m}$ elevation. Transition from debris to rock cliff is at approximately 4,300 $\mathrm{m}$ elevation. Bottom of photo is at approximately $3,600 \mathrm{~m}$ elevation. The debris avalanche likely became airborne at about 3,900 $\mathrm{m}$ elevation and fell $500 \mathrm{~m}$ to the Langtang Valley below located at $3,400 \mathrm{~m}$ elevation. 


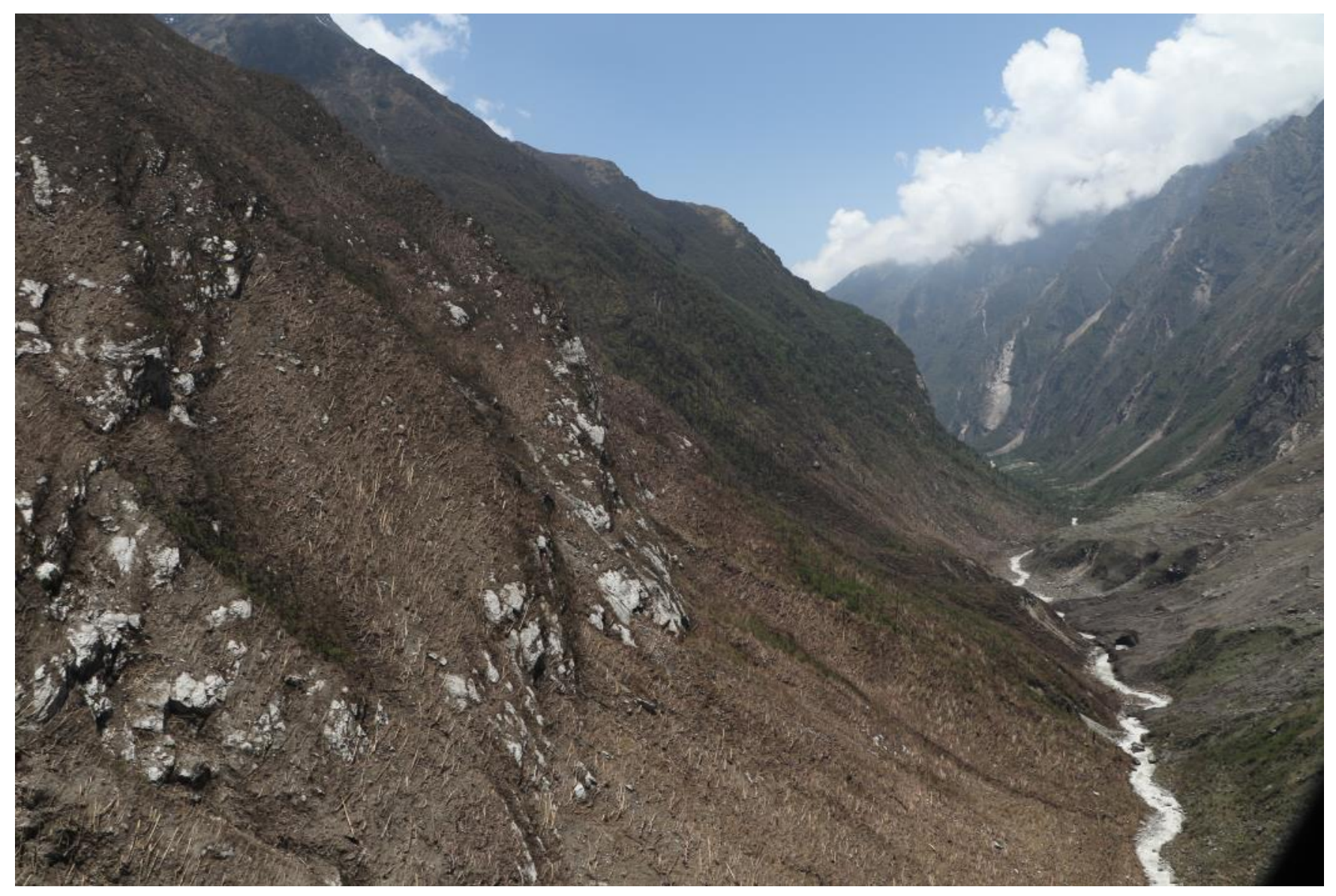

Figure 20. Photograph showing blown down trees caused by rapid emplacement of the Langtang debris avalanche deposit and resulting radial air blast. The air blast flattened all parts of the village not originally buried by debris and caused blowdown of trees in all directions for a distance of approximately $1 \mathrm{~km}$. View is down-valley to the west and shows approximately 1,000 $\mathrm{m}$ of vertical relief between river and foreground mountain. 


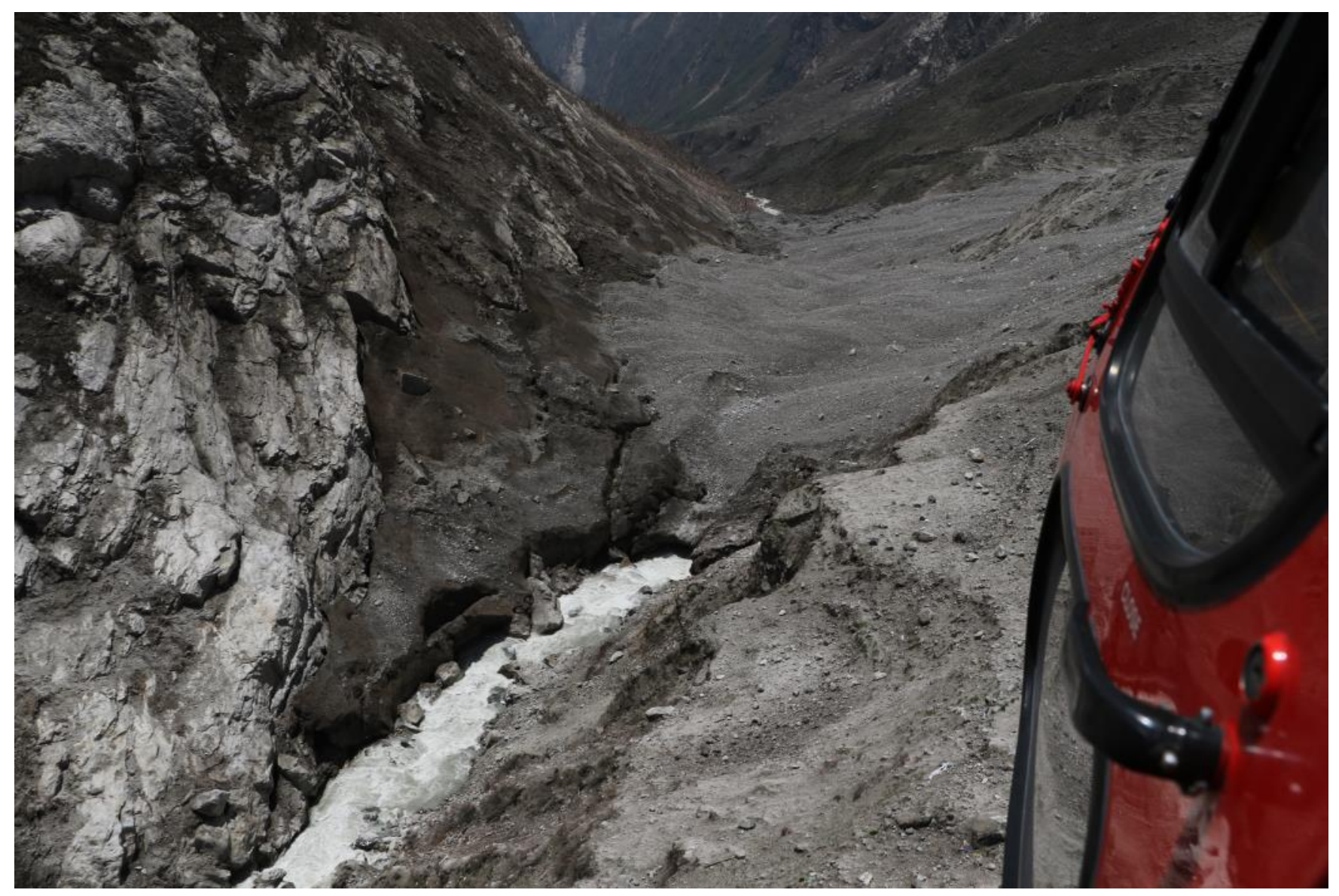

Figure 21. Photograph showing the Langtang debris avalanche deposit temporarily blocking the flow of the Langtang River, which subsequently formed a tunnel through the ice in which the river was flowing through in May 2015. River in foreground is approximately $10 \mathrm{~m}$ wide. Tunnel through ice and debris is approximately $650 \mathrm{~m}$ long. 


\section{Tsho Rolpa Moraine Dam (Rolwaling River, Dolakha District)}

Tsho Rolpa is a glacial lake about $25 \mathrm{~km}$ east of the Tama Koshi River Valley in Dolakha district (fig. 8) that poses an ongoing threat of glacial lake outburst flood (GLOF) (Reynolds, 1999; Rana and others, 2000; Shrestha and Nakagawa, 2014). GLOFs have occurred in Nepal in the past (Cenderelli and Wohl, 2001; Kattelmann, 2003) and can pose serious hazards to downstream villages and hydropower plants.

The lake is at an elevation of 4,555 $\mathrm{m}$ and is $3.5 \mathrm{~km}$ long by $0.6 \mathrm{~km}$ wide. It is impounded by a terminal moraine from the Trakarding Glacier (fig. 22). Because of the non-engineered composition of the impounding material, the steepness $\left(30^{\circ}\right)$ of the downslope surface of the moraine, the nearovertopping elevation of the glacial lake, and the possibility of tsunami overtopping from large landslides into the lake from the steep adjacent slopes, an engineered outlet was constructed for the lake in 2000 (Rana and others, 2000). The outlet structure (fig. 23) consists of three adjustable steel sluice gates located at the end of an approximately 24-m-wide, $80-\mathrm{m}$-long outlet channel. The sluice gates are manually operated and allow for controlled release of water without consequent erosion and failure of the natural dam. The primary concern at Tsho Rolpa was that the earthquakes might have damaged the outlet structure or that the natural dam itself and the stability of the moraine might be compromised and result in a GLOF.

The inlet to the control structure at the lake consists of a widening channel with somewhat lowangle $\left(10^{\circ}\right)$ sideslopes composed of spoil from the outlet excavation. Both flanks of this channel underwent lateral-spread landsliding during one or both of the major earthquakes. We estimated horizontal displacements to be about 1.0-1.5 m and vertical displacements to be about $0.5 \mathrm{~m}$ (fig. 24). The spreading on both sides was eastward, toward the lake rather than toward the channel, and did not compromise the integrity of the inlet channel. In our judgment, this lateral spreading does not pose a significant threat to the stability of the lake or its outlet.

We also inspected the entire impounding moraine from the terminal moraine all the way eastward to the glacier from the air and saw no cracks or other evidence that the natural dam was damaged by the earthquake or that the stability of the lake was in danger. Due to the high altitude and abundance of steep rock cliffs adjacent to the lake, we were not able to ascertain whether incipient landslides formed on these slopes as a result of the earthquakes or whether any landslides could pose additional hazards to lake-tsunami generation. 


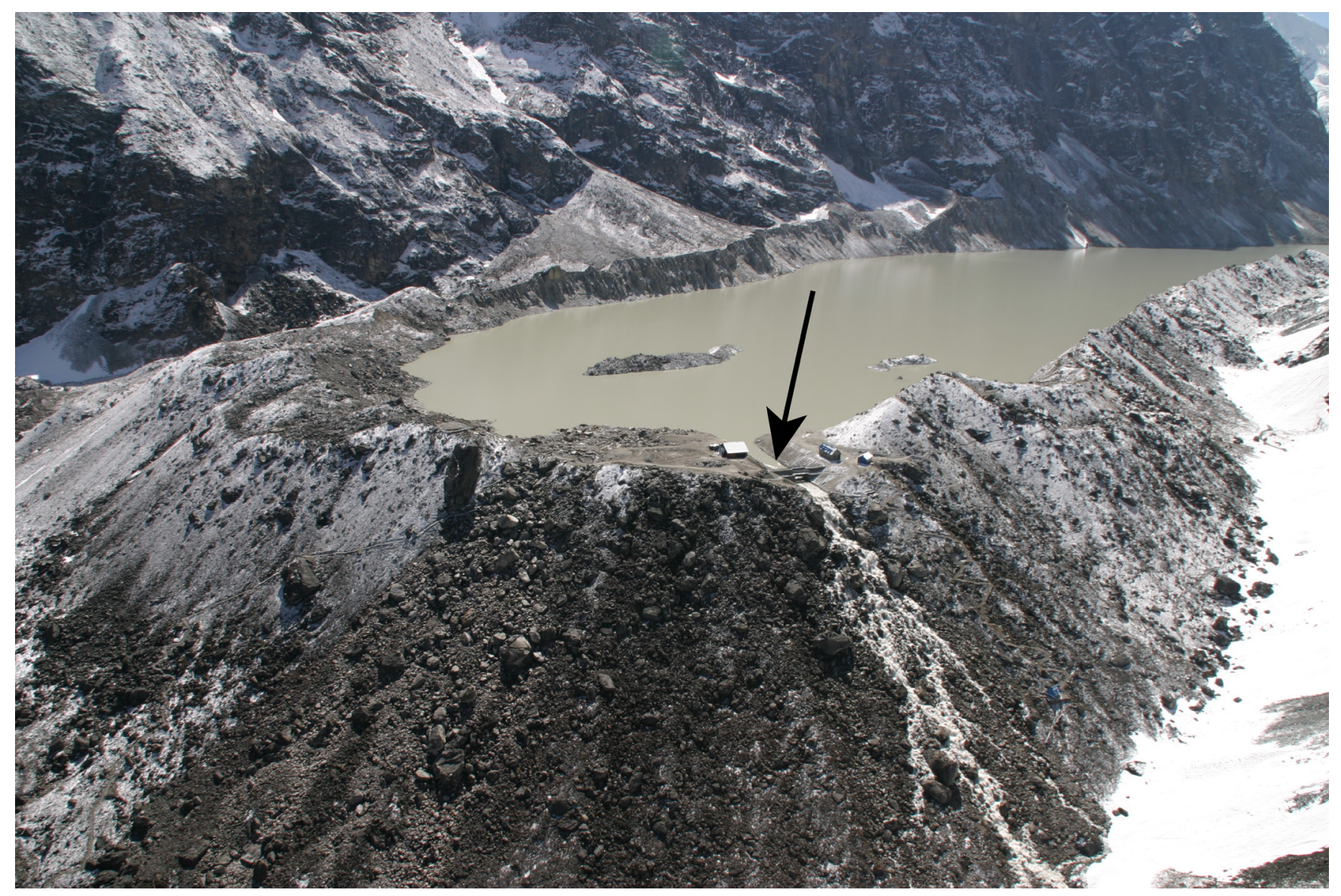

Figure 22. Photograph showing eastward view of the terminal moraine forming Tsho Rolpa glacial lake. The engineering outlet works (fig. 23) are indicated by an arrow. 


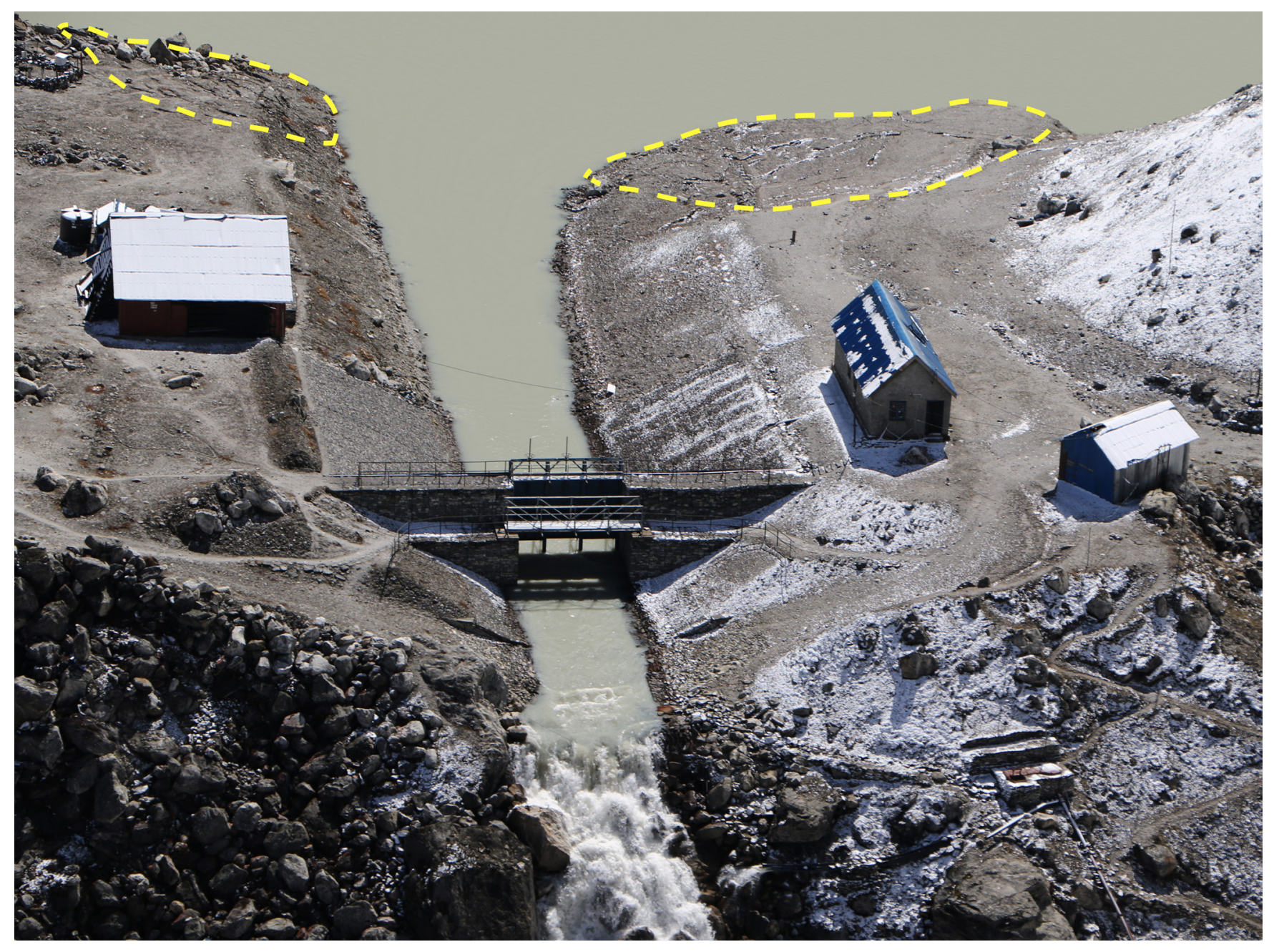

Figure 23. Photograph showing the sluice gates used to control the lake elevation at Tsho Rolpa. Areas of lateral spreading (fig. 24) are visible at the lake end of the channel (dashed yellow lines). 

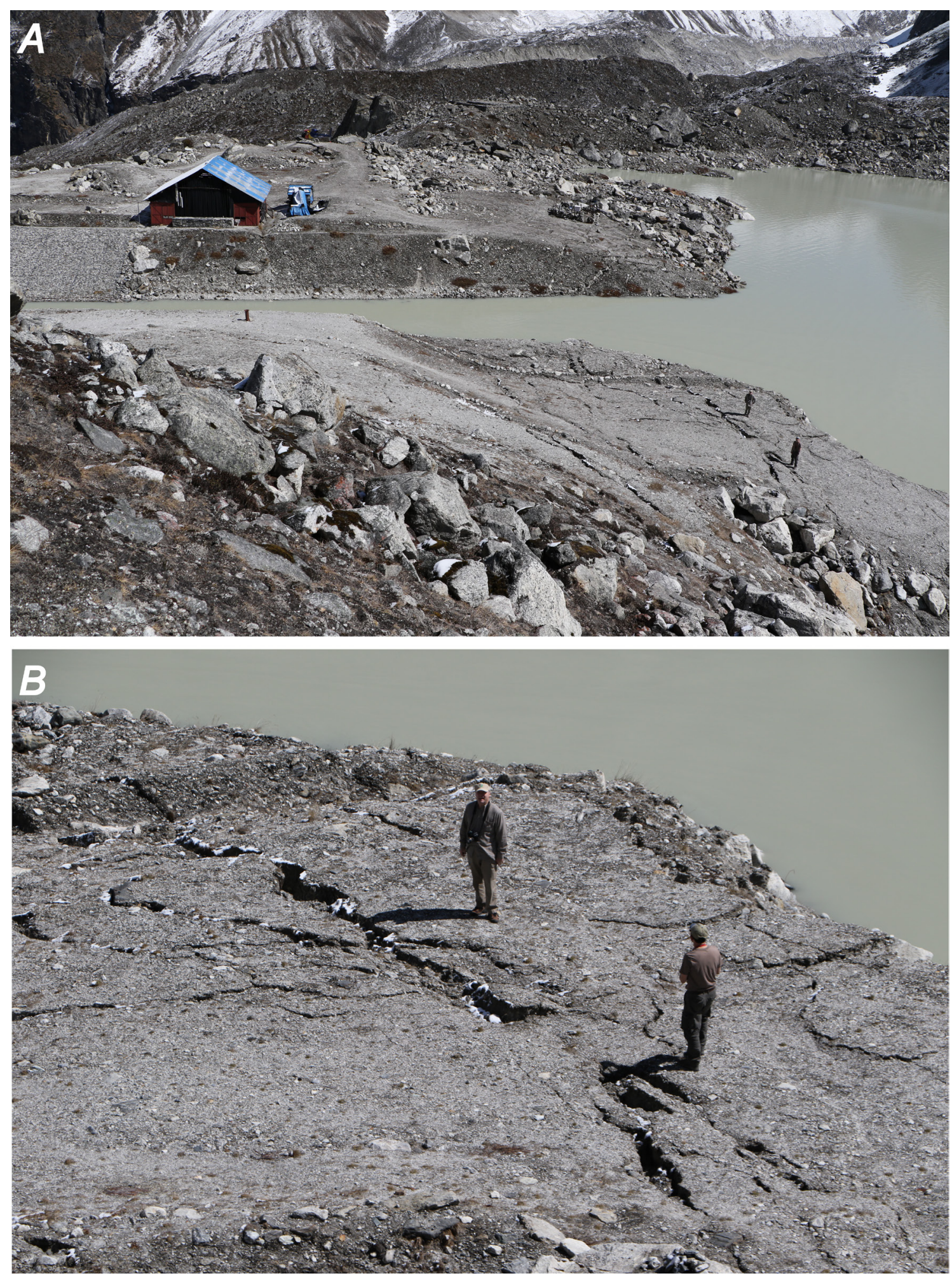

Figure 24. Photographs showing lateral spreading at the inlet to the Tsho Rolpa engineered drainage channel $(A$, $B$ ). Approximately $1.0-1.5 \mathrm{~m}$ of horizontal displacement (toward the lake) and $0.5 \mathrm{~m}$ of downward displacement on the eastern side of the channel did not appear to compromise the stability of the moraine dam or engineered outlet. 


\section{Potential Landslide Hazards Associated with the 2015 Summer Monsoon}

Landslide hazards created by the 2015 Gorkha, Nepal earthquake sequence could be exacerbated by 2015 summer monsoon rainfall. In normal conditions, the annual wet season in Nepal triggers landslides on the highly susceptible slopes in many parts of the country. Landscape disturbance by the 2015 earthquakes could significantly worsen landslide susceptibility in future monsoons, for a period of at least a few years.

\section{Valley-Blocking Landslides}

Hazards from valley-blocking landslides triggered by the 2015 earthquakes are evaluated in this report (table 1, fig. 9). The majority of valley-blocking landslides are considered to pose little hazard because they have already breached safely or are relatively permeable and did not impound a reservoir. Our evaluation, however, was conducted in low-water conditions at the end of the dry season. When river and stream discharges increase during the monsoon season, hazards from some valley-blocking landslides could increase as a result of the following situations: (1) Heavy rainfall could renew landslide movement resulting in extension or enlargement of existing landslide dams that had previously breached safely; this could lead to impoundment of water and renewed downstream threats; (2) Valley-blocking landslides that are permeable enough to pass water without impoundment during low-water conditions might not be able to transmit larger discharges during the wet season. Again, this could lead to hazards from impoundment of ponds or lakes above these landslide dams and subsequent rapid draining from overtopping, erosion, or piping. In addition, the earthquake shaking caused ground cracking and incipient landsliding in many places. Partially detached landslide masses that did not move all the way to valley bottoms could be reactivated in wetter conditions and move downslope to block valleys.

\section{Partially Detached Landslide Masses}

In addition to triggering thousands of landslides, the earthquakes also triggered incipient landslide movement in many slopes. In such cases, landslide masses detached from the parent slope and began to move downward, but they did not fully mobilize and continue moving to the bottom of the slope. When such masses become saturated during monsoon rains, they could remobilize. In wetter conditions, landslide material has the potential to move either as intact blocks or to disaggregate and mobilize as a debris flow, which can travel farther and faster than other types of landslides.

\section{Increased Landslide Susceptibility}

We observed pervasive ridge-top fracturing throughout the epicentral region. These fractures are most prevalent parallel to and along the upper edges of steep ridges. Fracturing at other locations on the flanks of steep slopes was also common. Open fractures on landslide-susceptible slopes facilitate increased infiltration of rainfall runoff; this, in turn, leads to an increase in pore-water pressure within these slopes, which substantially decreases their stability and increases the likelihood of landsliding. Seismically triggered fracturing of slopes can significantly increase the likelihood of additional landsliding during future monsoon seasons.

\section{Remobilization of Landslide Material}

A large volume of landslide material has been deposited in valley bottoms, gullies, and on the flanks of slopes throughout the epicentral region. When saturated by heavy monsoon rains, this material has the potential to remobilize into potentially damaging debris flows that can travel rapidly for long 
distances. Areas downstream of areas of pervasive landsliding could experience continuing debris-flow hazard throughout the current as well as future monsoon seasons.

Landslide material generated by the 2015 Gorkha, Nepal earthquake sequence will move down through the fluvial system over the next several years. Other areas struck by large earthquakes have experienced substantial increases in sedimentation rates on annual and decadal scales (Keefer, 1994; Keefer and others, 2003; Dadson and others, 2004; Lin and others, 2004). This increased sedimentation can have serious consequences for dams, power stations, water-treatment facilities, and other downstream civil works. In downstream areas, water quality may also be affected by the increase in suspended sediment in water supplies.

\section{Conclusions}

The Gorkha earthquake sequence that occurred in central Nepal in April and May 2015 led to considerable loss of life throughout the country. Hundreds of these fatalities were caused by landslides, including the particularly destructive Langtang debris avalanche. We estimate that a few tens of thousands of landslides were triggered by the earthquake sequence and that these landslides were distributed over an area of approximately $35,000 \mathrm{~km}^{2}$ in Nepal. Surprisingly, given the large earthquake magnitude and the exceedingly steep topography of the central Nepal Himalayan region, few extremely large $\left(>250,000 \mathrm{~m}^{3}\right)$ landslides were triggered.

Landsliding from the earthquake blocked many rivers and impounded lakes behind landslide dams. Although nearly all of these lakes were breached within one month following the earthquake, hazards remain in many areas. Continuing hazards include reactivation of partially-mobilized landslides into river channels, creation of new landslide dams and impoundments having potential for rapid release of water with increased precipitation during the 2015 monsoon, and potential debris flows from valley bottoms now filled with large volumes of newly released sediment.

Given Nepal's steep terrain and exposure to heavy precipitation from monsoon storms, landslides are a common occurrence in most years. However, vulnerability may increase during the 2015 summer (monsoon) season, as well as for several subsequent seasons, as a result of the widespread landslides and ground fracturing that occurred from the 2015 earthquakes. In this report, we have presented preliminary landslide hazard assessments for many areas within the earthquake-affected zone of central Nepal (tables 1 and 2) and described what we believe to be the most significant factors in assessing expected landslide hazards in the 2015 summer monsoon season. The data and interpretations presented in this report provide in-country agencies with information to plan for future landslide hazards.

\section{References Cited}

Ambraseys, N.N., and Douglas, J., 2004, Magnitude calibration of north Indian earthquakes: Geophysical Journal International, v. 159, no. 1, p. 165-206, doi:10.1111/j.1365-246X.2004.02323.x. Auden, J.B., and Ghosh, A.M.N., 1934, Preliminary account of the earthquake of the 15th January, 1934 in Bihar and Nepal: Records of the Geological Survey of India, v. 68, p. 177-239.

Bilham, Roger, 1995, Location and magnitude of the 1833 Nepal earthquake and its relation to the rupture zones of contiguous great Himalayan earthquakes: Current Science, v. 69, no. 2, p. 155-187.

Bilham, Roger, 2004, Earthquakes in India and the Himalaya - tectonics, geodesy and history: Annals of Geophysics, v. 47, no. 2, p. 839-858. 
Cenderelli, D.A., and Wohl, E.E., 2001, Peak discharge estimates of glacial-lake outburst floods and "normal" climatic floods in the Mount Everest region, Nepal: Geomorphology, v. 40, no. 1-2, p. 5790.

Chow, V.T., 1959, Open-channel Hydraulics: New York, McGraw-Hill, 680 p.

Collins, B.D. and Jibson, J.W., 2015, Video data files to accompany USGS OFR 2015-1142-Assessment of existing and potential landslide hazards resulting from the April 25, 2015 Gorkha, Nepal earthquake sequence: U.S. Geological Survey Data Release, http://dx.doi.org/10.5066/F7X928BN.

Costa, J.E., and Schuster, R.L., 1988, The formation and failure of natural dams: Geological Society of America Bulletin, v. 100, no. 7, p. 1054-1068.

Dadson, S.J., Hovius, Niels., Chen, Hongey, Dade, W.B., Lin, J.C., Hsu, M.L., Lin, C.W., Horng, M.J., Chen, T.C., Milliman, John, and Stark, C.P., 2004, Earthquake-triggered increase in sediment delivery from an active mountain belt: Geology, v. 32, no. 8, p. 733-736.

Evans, S.G., Hungr, Oldrich, and Clague, J.J., 2001, Dynamics of the 1984 rock avalanche and associated distal debris flow on Mount Cayley, British Columbia, Canada; implications for landslide hazard assessment on dissected volcanoes: Engineering Geology, v. 61, no. 1, p. 29-51.

Fort, Monique, 2011, Two large Late Quaternary rock slope failures and their geomorphic significance, Annapurna Himalayas (Nepal): Geografia Fisica e Dinamica Quaternaria, v. 34, no. 1, p. 5-16.

Hagen, Toni, 1968, Report on the Geological Survey of Nepal, volume 2 - Geology of the Thakkhola: Denkschriften der Schweizerischen Naturforschenden Gesellschaft, v. 86, no. 2, 160 p.

Highland, Lynn, 2004, Landslide types and processes: U.S. Geological Survey Fact Sheet 2004-3072, 4 p. [Also available at http://pubs.usgs.gov/fs/2004/3072/.]

Jibson, R.W., Harp, E.L., Schulz, William, and Keefer, D.K., 2004, Landslides triggered by the 2002 Denali Fault, Alaska, earthquake and the inferred nature of the strong shaking: Earthquake Spectra, $\mathrm{v}$. 20, no. 3, p. 669-691.

Jibson, R.W., Harp, E.L., Schulz, William, and Keefer, D.K., 2006, Large rock avalanches triggered by the M7.9 Denali Fault, Alaska, earthquake of 3 November 2002: Engineering Geology, v. 83, no. 1-3, p. 144-160.

Kattelmann, Richard, 2003, Glacial lake outburst floods in the Nepal Himalaya-A manageable hazard?: Natural Hazards, v. 28, no. 1, p. 145-154.

Keefer, D.K., 1984, Landslides caused by earthquakes: Geological Society of America Bulletin, v. 95 , no. 4, p. 406-421.

Keefer, D.K., 1994, The importance of earthquake-induced landslides to long-term erosion and slopefailure hazards in seismically active areas: Geomorphology, v. 10, no. 1, p. 265-284.

Keefer, D.K., 2002, Investigating landslides caused by earthquakes - A historical review: Surveys in Geophysics, v. 23, no. 6, p. 473-510.

Keefer, D.K., Moseley, M.E., and deFrance, S.D., 2003, A 38 000-year record of floods and debris flows in the Ilo region of southern Peru and its relations to El Niño events and great earthquakes: Palaeogeography, Palaeoclimatology, Palaeoecology, v. 194, p. 41-77.

Lin, C.W., Shieh, C.L., Yuan, B.D., Shieh, Y.C., Liu, S.H., and Lee, S.Y., 2004, Impact of Chi-Chi earthquake on the occurrence of landslides and debris flows; example from the Chenyulan River watershed, Nantou, Taiwan: Engineering Geology, v. 71, no. 1-2, p. 49-61.

Malamud, B.D., Turcotte, D.L., Guzzetti, Fausto, and Reichenbach, Paola, 2004, Landslide inventories and their statistical properties: Earth Surface Processes and Landforms, v. 29, no. 6, p. 687-711. 
Petley, D.N., Hearn, G.J., Hart, Andrew, Rosser, N.J., Dunning, S.A., Oven, K., and Mitchell, W.A., 2007, Trends in landslide occurrence in Nepal: Natural Hazards, v. 43, no. 1, p. 23-44, doi:10.1007/s11069-006-9100-3.

Plafker, George, Ericksen, G.E., and Fernández, C.J., 1971, Geological aspects of the May 31, 1970, Perú earthquake: Bulletin of the Seismological Society of America, v. 61, no. 3, p. 543-578.

Rana, Birbal, Shrestha, A.B., Reynolds, J.M., Aryal, Raju, Pokhrel, A.P., and Budhathoki, K.P., 2000, Hazard assessment of the Tsho Rolpa Glacier Lake and ongoing remediation measures: Journal of Nepal Geological Society, v. 22, p. 563-570.

Reynolds, J.M., 1999, Glacial hazard assessment at Tsho Rolpa, Rolwaling, Central Nepal: Quarterly Journal of Engineering Geology and Hydrogeology, v. 32, no. 3, p. 209-214, doi:10.1144/GSL.QJEG.1999.032.P3.01.

Shrestha, B.B., and Nakagawa, Hajime, 2014, Assessment of potential outburst floods from the Tsho Rolpa glacial lake in Nepal: Natural Hazards, v. 71, no. 1, p. 913-936.

Singh, D.D., and Gupta, H.K., 1980, Source dynamics of two great earthquakes of the Indian subcontinent - The Bihar-Nepal earthquake of January 15, 1934 and the Quetta earthquake of May 30, 1935: Bulletin of the Seismological Society of America, v. 70, no. 3, p. 757-773.

Varnes, D.J., 1978, Slope movement types and processes, in Schuster, R.L., and Krizek, R.J., eds., Landslides-Analysis and control: Transportation Research Board Special Report, no. 176, p. 11-33.

Voight, Barry, and Sousa, James, 1994, Lessons from Ontake-san-A comparative analysis of debris avalanche dynamics: Engineering Geology, v. 38, no. 3-4, p. 261-297.

Weidinger, J.T., 2006, Predesign, failure and displacement mechanisms of large rockslides in the Annapurna Himalayas, Nepal: Engineering Geology, v. 83, no. 1-3, p. 201-216. 


\section{Appendix 1. Video and Geographic Reference Files from Helicopter Reconnaissance}

The video files contained herein and available for download at http://dx.doi.org/10.5066/

F7X928BN are divided into geographic areas according to the day in which they were collected. For each day (for example, 05/30/2015 - note the U.S. date format MM/DD/YYYY), the files are further subdivided by point-to-point paths denoted by a letter (for example, -A, -B, -C) which correspond to the start and end village and geographic coordinate positions listed in table A1. In most cases, we use the name of the nearest village to identify these positions. A Google Earth .kmz file accompanies the video file collection. Google Earth (https:/www.google.com/earth/) is a freely-downloadable web-based geographic information system (GIS) that allows users to locate themselves on available satellite and aerial imagery. The .kmz file contains the following information for each flight of each day: (1) video starting point, (2) view point locations of all sites with detailed assessments (that is, all sites listed in table 2), (3) video ending point, and (4) a polygon delineating the approximate area that each video path covers. By viewing the video files at the same time as the Google Earth files, users can follow flight paths and determine the georeferenced location of features visible in the videos. 
Table A1. Helicopter video file log.

\begin{tabular}{|c|c|c|c|c|c|c|c|c|c|c|}
\hline File name ${ }^{1}$ & District(s) & Start location ${ }^{2}$ & End location ${ }^{2}$ & $\begin{array}{l}\text { Duration } \\
\text { (minutes) }\end{array}$ & $\begin{array}{l}\text { Video } \\
\text { file size } \\
\text { (GB) }\end{array}$ & $\begin{array}{l}\text { Latitude } \\
\text { at start of } \\
\text { video } \\
\left({ }^{\circ} \mathrm{N}\right)\end{array}$ & $\begin{array}{l}\text { Longitude } \\
\text { at start of } \\
\text { video } \\
\left({ }^{\circ} \mathrm{E}\right)\end{array}$ & $\begin{array}{l}\text { Latitude } \\
\text { at end of } \\
\text { video } \\
\left({ }^{\circ} \mathrm{N}\right)\end{array}$ & $\begin{array}{l}\text { Longitude } \\
\text { at end of } \\
\text { video } \\
\left({ }^{\circ} \mathrm{E}\right)\end{array}$ & $\begin{array}{l}\text { Notable locations and corresponding } \\
\text { times (@X:XX) within each video file }\end{array}$ \\
\hline 05272015-A & Dolakha & Khanidada & Simigau & $5: 35$ & 0.95 & 27.8068 & 86.2088 & 27.8728 & 86.2304 & Simigau village @2:46 \\
\hline 05272015-B & Dolakha & Simigau & Tsho Rolpa & $21: 28$ & 3.57 & 27.8729 & 86.2303 & 27.8700 & 86.4625 & Tsho Rolpa moraine dam @11:29 \\
\hline 05272015-C & Dolakha & Tsho Rolpa & Bedin & 9:00 & 1.52 & 27.8699 & 86.4624 & 27.9015 & 86.3768 & \\
\hline 05272015-D & Dolakha & Bedin & Simigau & $6: 53$ & 1.14 & 27.9015 & 86.3768 & 27.8708 & 86.2346 & \\
\hline 05272015-E & Dolakha & Simigau & Lapchegau & $16: 16$ & 2.73 & 27.8721 & 86.2312 & 28.1173 & 86.1696 & \\
\hline 05272015-F & Dolakha & Lapchegau & Simigau & 23:00 & 3.82 & 28.1163 & 86.1696 & 27.8729 & 86.2303 & \\
\hline 05272015-G & Dolakha & Simigau & Singati Bajar & $12: 13$ & 2.05 & 27.8729 & 86.2303 & 27.7373 & 86.1695 & \\
\hline 05272015-H & Dolakha & Singati Bajar & Dihi & $12: 25$ & 2.05 & 27.7372 & 86.1694 & 27.6516 & 86.0893 & \\
\hline 05272015-I & Sindhupalchok & Khadichaur & Guna Gadhi & $16: 27$ & 2.72 & 27.7463 & 85.8088 & 27.9173 & 85.9225 & $\begin{array}{l}2014 \text { landslide dam on the Sun Koshi } \\
\text { River @2:13 }\end{array}$ \\
\hline 05272015-J & Sindhupalchok & Kodari & Guna Gadhi & $6: 29$ & 1.09 & 27.9589 & 85.9550 & 27.9164 & 85.9174 & $\begin{array}{l}\text { Kodari rock falls @2:10; Guna Gadhi } \\
\text { shattered ridgetop @5:23 }\end{array}$ \\
\hline 05272015-K & $\begin{array}{l}\text { Sindhupalchok, } \\
\text { Kavrepalanchok, } \\
\text { Kathmandu }\end{array}$ & Guna Gadhi & Kathmandu & $29: 42$ & 5.05 & 27.9163 & 85.9174 & 27.6975 & 85.3620 & \\
\hline 05282015-A & Rasuwa & Ghodatabela & Kyanjin Gompa & $23: 03$ & 3.85 & 28.2008 & 85.4611 & 28.2114 & 85.5681 & Kyanjin Gompa village @22:18 \\
\hline 05282015-B & Rasuwa & Kyanjin Gompa & Langtang & $19: 55$ & 3.36 & 28.2114 & 85.5680 & 28.2163 & 85.5095 & Langtang debris avalanche @6:21 \\
\hline 05282015-C & Rasuwa & Langtang & Ghodatabela & $9: 44$ & 1.66 & 28.2164 & 85.5094 & 28.2010 & 85.4610 & \\
\hline 05282015-D & Rasuwa & Ghodatabela & Dal & $18: 28$ & 3.09 & 28.2008 & 85.4610 & 28.2219 & 85.3596 & \\
\hline 05282015-E & $\begin{array}{l}\text { Kathmandu, } \\
\text { Dhading, } \\
\text { Nuwakot }\end{array}$ & Kathmandu & Biruwatar & $15: 09$ & 2.50 & 27.6972 & 85.3623 & 27.8180 & 85.0448 & \\
\hline 05282015-F & $\begin{array}{l}\text { Nuwakot, Dhading, } \\
\text { Gorkha }\end{array}$ & Biruwatar & Pokhartar & $17: 43$ & 2.97 & 27.8187 & 85.0445 & 28.1436 & 84.6991 & \\
\hline
\end{tabular}




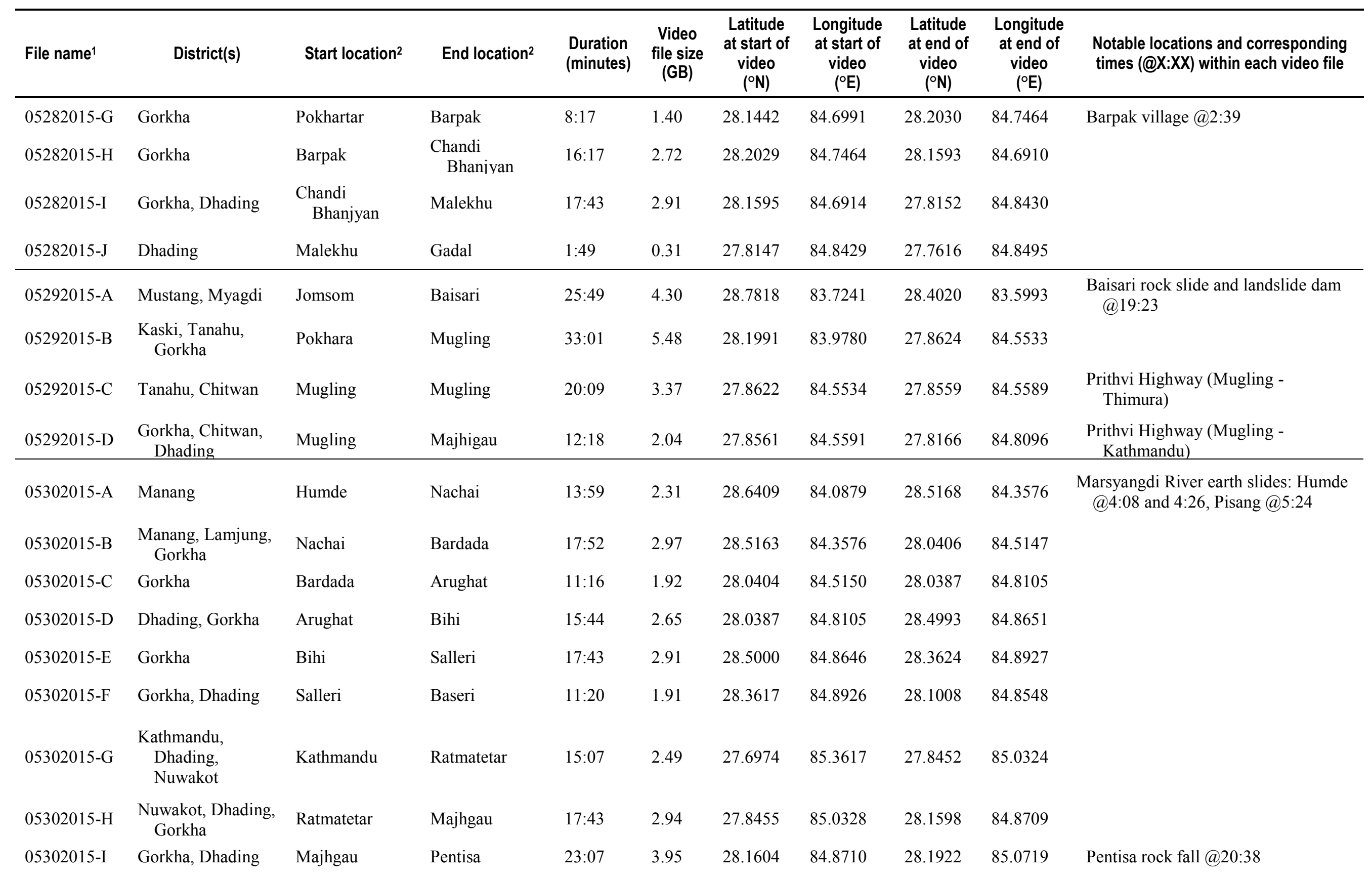




\begin{tabular}{|c|c|c|c|c|c|c|c|c|c|c|}
\hline File name ${ }^{1}$ & District(s) & Start location ${ }^{2}$ & End location ${ }^{2}$ & $\begin{array}{l}\text { Duration } \\
\text { (minutes) }\end{array}$ & $\begin{array}{c}\text { Video } \\
\text { file size } \\
\text { (GB) }\end{array}$ & $\begin{array}{l}\text { Latitude } \\
\text { at start of } \\
\text { video } \\
\left({ }^{\circ} \mathrm{N}\right)\end{array}$ & $\begin{array}{l}\text { Longitude } \\
\text { at start of } \\
\text { video } \\
\left({ }^{\circ} \mathrm{E}\right)\end{array}$ & $\begin{array}{l}\text { Latitude } \\
\text { at end of } \\
\text { video } \\
\text { ('N) }\end{array}$ & $\begin{array}{l}\text { Longitude } \\
\text { at end of } \\
\text { video } \\
\left({ }^{\circ} \mathrm{E}\right)\end{array}$ & $\begin{array}{l}\text { Notable locations and corresponding } \\
\text { times (@X:XX) within each video file }\end{array}$ \\
\hline 05302015-J & $\begin{array}{l}\text { Dhading, Nuwakot, } \\
\text { Kathmandu }\end{array}$ & Pentisa & Kathmandu & $22: 58$ & 3.89 & 28.1922 & 85.0719 & 27.6976 & 85.3620 & \\
\hline 06012015-A & Sindhupalchok & Melamchigau & $\begin{array}{l}\text { Urkin Kangari } \\
\text { Valley }\end{array}$ & $17: 19$ & 2.93 & 28.0190 & 85.5273 & 28.0972 & 85.5471 & $\begin{array}{l}\text { Urkin Kangari Valley rock slide } \\
\text { @3:50 }\end{array}$ \\
\hline 06012015-B & Sindhupalchok & $\begin{array}{l}\text { Urkin Kangari } \\
\text { Valley }\end{array}$ & Melamchigau & $20: 06$ & 3.36 & 28.0971 & 85.5472 & 28.0190 & 85.5273 & Melamchigau village @18:41 \\
\hline 06012015-C & Sindhupalchok & Melamchigau & Thanpalkot area & $25: 42$ & 4.26 & 28.0190 & 85.5273 & 27.9111 & 85.6973 & Thanpalkot earth flow @25:01 \\
\hline 06012015-D & Gorkha & Arughat & Kerauja & $23: 53$ & 4.11 & 28.0389 & 84.8103 & 28.2315 & 84.9059 & \\
\hline 06012015-E & Gorkha, Dhading & Kerauja & Arughat & $26: 23$ & 4.44 & 28.2316 & 84.9060 & 28.0390 & 84.8104 & Kerauja rock slide @1:50 \\
\hline 06012015-F & Dhading & Arughat & Phulkharka area & $4: 14$ & 0.72 & 28.0384 & 84.8107 & 28.0679 & 84.9336 & \\
\hline
\end{tabular}

${ }^{1}$ All file names begin with "USGS_Nepal_".

${ }^{2}$ Name is generaelly labeled as the nearest village to the start or end of the video file. 